Article

\title{
Synthesis and Fungicidal Activity of Hydrated Geranylated Phenols against Botrytis cinerea
}

\author{
Mauricio Soto ${ }^{1,2}$, Ana Estevez-Braun ${ }^{2} \mathbb{D}$, Ángel Amesty ${ }^{2}$, Julia Kluepfel ${ }^{3}$, Susana Restrepo ${ }^{1}$, Katy Diaz ${ }^{1} \mathbb{D}$, \\ Luis Espinoza ${ }^{1} \mathbb{D}$, Andrés F. Olea ${ }^{4, *} \mathbb{D}$ and Lautaro Taborga $1, * \mathbb{D}$
}

1 Departamento de Química, Universidad Técnica Federico Santa María, Av. España No. 1680, Valparaíso 2340000, Chile; mauricio.sotoc.13@sansano.usm.cl (M.S.); susana.restrepo@usm.cl (S.R.); katy.diaz@usm.cl (K.D.); luis.espinozac@usm.cl (L.E.)

2 Instituto Universitario de Bio-Orgánica Antonio González (CIBICAN), Departamento de Química Orgánica, Universidad de La Laguna, Av. Astrofísico Fco, Sánchez 2, 38206 La Laguna, Spain; aestebra@ull.edu.es (A.E.-B.); aarnesty@ull.es (Á.A.)

3 Department of Chemistry, Technical University of Munich, Lichtenberg Str. 4, 85748 Garching, Germany; julia.kluepfel@tum.de

4 Grupo de Química y Bioquímica Aplicada en Biotecnología, Instituto de Ciencias Químicas Aplicadas, Facultad de Ingeniería, Universidad Autónoma de Chile, El Llano Subercaseaux 2801, Santiago 8900000, Chile

* Correspondence: andres.olea@uautonoma.cl (A.F.O.); lautaro.taborga@usm.cl (L.T.); Tel.: +56-32-265-2840 (L.T.)

check for updates

Citation: Soto, M.; Estevez-Braun, A.; Amesty, Á.; Kluepfel, J.; Restrepo, S.; Diaz, K.; Espinoza, L.; Olea, A.F.;

Taborga, L. Synthesis and Fungicidal Activity of Hydrated Geranylated Phenols against Botrytis cinerea. Molecules 2021, 26, 6815. https:// doi.org/10.3390/molecules26226815

Academic Editor:

Domenico Trombetta

Received: 19 October 2021

Accepted: 9 November 2021

Published: 11 November 2021

Publisher's Note: MDPI stays neutral with regard to jurisdictional claims in published maps and institutional affiliations.

Copyright: (c) 2021 by the authors. Licensee MDPI, Basel, Switzerland. This article is an open access article distributed under the terms and conditions of the Creative Commons Attribution (CC BY) license (https:// creativecommons.org/licenses/by/ $4.0 /)$.
Abstract: Botrytis cinerea is a ubiquitous fungus that affects hundreds of plants, resulting in economic losses to the horticulture and fruit industry. The search for new antifungal agents is a matter of current interest. Thus, in this work a series of geranylated phenols in which the side alkyl chain has been hydrated have been synthesized, and their activity against $B$. cinerea has been evaluated. The coupling of phenol and geraniol has been accomplished under microwave irradiation obtaining the highest reaction yields in the shortest reaction times. Hydration of the side chain was carried out in dioxane with $p$-toluenesulfonic acid polymer-bound as the catalyst. All synthesized compounds were tested against $B$. cinerea using the growth inhibition assay and $\mathrm{EC}_{50}$ values were determined. The results show that activity depends on the number and nature of functional groups in the phenol ring and hydration degree of the geranyl chain. The most active compound is 1,4-dihydroquinone with one hydroxyl group attached at the end of the alkyl chain. Results from a molecular docking study suggest that hydroxyl groups in the phenol ring and alkyl chain are important in the binding of compounds to the active site, and that the experimental antifungal activity correlates with the number of $\mathrm{H}$-bond that can be formed in the binding site.

Keywords: Botrytis cinerea; hydrated geranylated phenols; docking; synthesis; fungicidal

\section{Introduction}

Geranylated phenols and their hydrated derivatives are an important class of secondary metabolites found mainly in marine organisms. They have been isolated from brown algaes (fucales), sponges [1,2], coral [3,4] and Ascidian (Aplidium) [5-8].

De Rosa et al. [1] have shown that biological activity of 2-prenyl-1,4-hydroquinones depends on the size of the prenyl chain, and the optimal length is in the range of five to fifteen carbon atoms. In previous work, we reported the synthesis of a series of geranylated phenols with different chemical substituents on the aromatic ring (see Figure 1). These compounds exhibited interesting biological activities, such as in vitro cytotoxicity on cancer cell lines [9,10], mycelial growth inhibition of Botrytis cinerea [11-14] and antifungal activity against Phytophthora cinnamomi [15]. The results indicate that the activity is enhanced mainly by the presence of $-\mathrm{OH},-\mathrm{OCH}_{3}$ and -OAc functions in the aromatic ring [11-13]. 


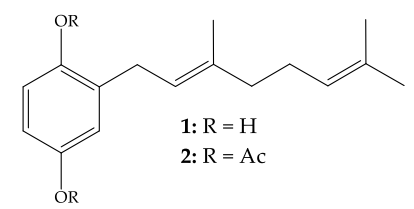<smiles>CC(C)=CCC/C(C)=C/Cc1ccc(O)c(C)c1</smiles><smiles>CC(C)=CCC/C(C)=C/Cc1cc(C)ccc1O</smiles><smiles>COc1cc(O)c(C/C=C(/C)CCC=C(C)C)cc1O</smiles><smiles>CC(C)=CCC/C(C)=C/Cc1ccc(O)cc1O</smiles><smiles>CC(C)=CCC/C(C)=C/Cc1c(C)cc(O)cc1O</smiles><smiles>COc1c(O)ccc(CC=C(C)CCC=C(C)C)c1OC</smiles><smiles>COc1cc(C/C=C(\C)CCC=C(C)C)c(O)c(OC)c1OC</smiles>

Figure 1. Geranylated phenols with antifungal activity.

On the other hand, the effect of chemical modification of the side chain on antifungal activity has received much less attention, i.e., it has been shown that the hydrated derivative of 2-allylphenol exhibits antifungal activity against $P$. aphanidermatum, $V$. mali, B. cinerea and $R$. cereals [16], whereas some hydrated derivatives of geranylated phenols (Figure 2) inhibit the mycelial growth of B. cinerea [14].<smiles>Cc1cccc(CCC(C)(O)CCCC(C)(C)O)c1O</smiles><smiles>COc1cc(O)c(CCC(C)(O)CCCC(C)(C)O)cc1O</smiles><smiles>COc1cc(O)c(C/C=C(\C)CCCC(C)(C)O)cc1O</smiles><smiles>Cc1cc(CCC(C)(O)CCCC(C)(C)O)ccc1O</smiles>

Figure 2. Geranylated phenols with hydrated side chain.

Thus, the aim of this work is to carry out a systematic study of the effect of ring substitution and hydration of side chain on the activity of geranylated phenols against $B$. cinerea. Therefore, a series of geranylated phenols with and without hydroxyl groups in the side chain were synthesized, and their mycelial growth inhibition activity on $B$. cinerea was determined. The obtained data were used to establish a structure-activity relationship, whereas a molecular docking study was made to visualize the main interactions of these molecules into the active site.

\section{Results}

To establish a structure-activity relationship, between mycelial-growth inhibition of $B$. cinerea and chemical substitution on phenol ring and hydration in the side alkyl chain, four series of geranylated phenols have been synthesized. Antifungal activities against $B$. cinerea of all synthesized compounds were evaluated.

\subsection{Synthesis}

The synthesis of geranylated phenols is well described and generally it proceeds by direct coupling of geraniol with the proper phenol in the presence of $\mathrm{BF}_{3} \cdot \mathrm{OEt}_{2}$ as a catalyst and dioxane as solvent $[1,9,14,17-19]$. Alternatively, $\mathrm{BF}_{3} \cdot \mathrm{OEt}_{2} / \mathrm{AgNO}_{3}$ has been used as 
catalyst and acetonitrile as solvent [11,12]. The time reaction varies between 24 and $72 \mathrm{~h}$ and the yields are in the range of 3 to $12 \%$. In this work, this coupling reaction was carried out under microwave irradiation to obtain a series of geranylated phenols with different substituents on the phenolic ring (see Figure 3).<smiles>CC(C)=CCC/C(C)=C/Cc1ccc(O)c(C)c1</smiles><smiles>CC(C)=CCC/C(C)=C/Cc1ccc(O)cc1C</smiles><smiles>CC(C)=CCC/C(C)=C/Cc1ccc(C)cc1O</smiles><smiles>CC(C)=CCC/C(C)=C/Cc1cc(O)ccc1O</smiles><smiles>COc1cc(O)c(C/C=C(\C)CCC=C(C)C)c(OC)c1O</smiles><smiles>COC1=CC(=O)C(C/C=C(\C)CCC=C(C)C)=C(OC)C1=O</smiles><smiles>COc1cc(O)c(C/C=C(\C)CCC=C(C)C)cc1OC</smiles><smiles>CC(C)=CCC/C(C)=C/Cc1c(O)cc(O)cc1O</smiles>

Figure 3. Series of geranylated phenols synthesized by microwave irradiation using acetonitrile as solvent. Compounds $\mathbf{1 9}$ and 20 are new.

Compounds 3, 18, 16, 17, 21 and 22 have been described previously, whereas derivatives 19 and 20 are new compounds. Interestingly, coupling reactions under microwave irradiation proceed with higher yields (21-32\%) and reduced reaction time (10 min). For example, Scheme 1 shows the coupling reaction between o-cresol and geraniol giving compound 3. Under microwave irradiation, three is obtained with $22 \%$ yield after $10 \mathrm{~min}$, while in absence of irradiation the reaction yield is $3 \%$ after $48 \mathrm{~h}$ of reaction [14].

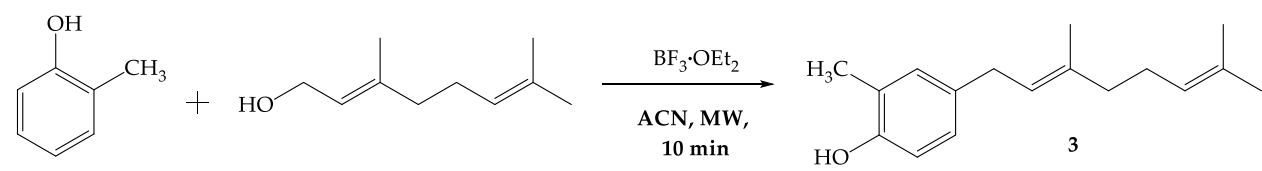

Scheme 1. Synthesis of geranylated phenol 3 under microwave irradiation.

On the other hand, there are just a few reports of hydration reaction of the side chain in geranylated phenols. Hydrated geranylated orcinol derivatives were obtained by a coupling reaction of geraniol and orcinol in the presence of oxalic acid $(1 \%)$ at $80^{\circ} \mathrm{C}$ [20]. No reaction yields were reported. Compounds 13 and 14 were synthesized by electrophilic addition of geraniol in dioxane and using $\mathrm{BF}_{3}$ as catalyst in the presence of water [14]. Herein, geranylated phenols were hydrated in dioxane containing water and using $p$ toluenesulfonic acid bound to a polymer matrix as catalyst. In this way, two series of new mono- and di-hydrated geranylated phenols (Figures 4 and 5, respectively) were obtained. 
<smiles>CC(=CCc1ccc(O)cc1O)CCCC(C)(C)O</smiles><smiles>CC(C)=CCCC(C)(O)CCc1ccc(O)cc1O</smiles><smiles>CC(C)=CCCC(C)(O)CCc1cc(O)ccc1O</smiles><smiles>C/C(=C\Cc1c(C)cc(O)cc1O)CCCC(C)(C)O</smiles><smiles>CC(C)=CCCC(C)(O)CCc1c(C)cc(O)cc1O</smiles><smiles>COc1c(O)ccc(CC=C(C)CCCC(C)(C)O)c1OC</smiles><smiles>COc1cc(O)c(C/C=C(\C)CCCC(C)(C)O)cc1OC</smiles><smiles>COc1cc(O)c(C/C=C(\C)CCCC(C)(C)O)c(OC)c1O</smiles><smiles>COC1=CC(=O)C(C/C=C(\C)CCCC(C)(C)O)C(OC)C1=O</smiles><smiles>CC(C)=CCC/C(C)=C/Cc1cc(C/C=C(\C)CCCC(C)(C)O)c(O)cc1O</smiles><smiles>CC(C)=CCCC(C)=CCc1cc(CCC(C)(O)CCC=C(C)C)c(O)cc1O</smiles>

Figure 4. Synthesized geranylated phenols with monohydrated side chain.<smiles>CC(C)(O)CCCC(C)(O)CCc1ccc(O)cc1O</smiles><smiles>CC(C)(O)CCCC(C)(O)CCc1cc(O)ccc1O</smiles><smiles>Cc1cc(O)cc(O)c1CCC(C)(O)CCCC(C)(C)O</smiles><smiles>COc1cc(O)c(CCC(C)(O)CCCC(C)(C)O)cc1OC</smiles><smiles>COc1cc(CCC(C)(O)CCCC(C)(C)O)c(O)c(OC)c1OC</smiles>

Figure 5. Geranylated phenols with di-hydrated side chain.

The reaction conditions and products of hydration of 4-geranylated orcinol are shown in Scheme 2.<smiles>CC(C)=CCCC(C)=CCc1c(C)cc(O)cc1O</smiles><smiles>CC(=CCc1c(C)cc(O)cc1O)CCCC(C)(C)O</smiles><smiles>CC(C)=CCCC(C)(O)CCc1c(C)cc(O)cc1O</smiles><smiles>Cc1cc(O)cc(O)c1CCC(C)(O)CCCC(C)(C)O</smiles>

Scheme 2. Synthesis of geranylated orcinol derivatives with mono-hydrated $(26,27)$ and di-hydrated side chain (36).

The product of this reaction is a mixture of hydrated compounds carrying one (26 and 27) or two hydroxyl groups (36). As can be seen, the product reaction is a mixture of hydrated compounds carrying one or two hydroxyl groups.

Structural Determination of Geranylated Orcinol Derivatives 26, 27 and 36. 
The chemical structure of hydrated geranylated phenols was established mainly by ${ }^{1} \mathrm{H},{ }^{13} \mathrm{C}$ (Figures S5, S6 and S15, Supplementary Material) and 2D NMR spectroscopy. The disappearance of double bonds in the side alkyl chain was verified in the ${ }^{1} \mathrm{H}-\mathrm{NMR}$ spectrum by signals appearing at $\delta=3.28(2 \mathrm{H}, d, J=6,8 \mathrm{~Hz}) ; \delta=5.13(1 \mathrm{H}, \mathrm{m}) ; \delta=1.40$ $(1 \mathrm{H}, \mathrm{m})$ assigned to $\mathrm{H}-1^{\prime}, \mathrm{H}-2^{\prime}$ and $\mathrm{H}-6^{\prime}$, respectively. These assignments were made by comparison with NMR spectra previously published for the respective geranylated phenol, and by $2 \mathrm{D}$ HMBC spectra. Figure 6 shows heteronuclear correlations at ${ }^{2} \mathrm{JCH}$ (blue) and ${ }^{3} \mathrm{JCH}$ (red) observed for compound 26, i.e., coupling at ${ }^{3} \mathrm{JCH}$ (red) between $\mathrm{H}-1^{\prime}$ and $\mathrm{C}-3^{\prime}$ $\left(\delta_{\mathrm{C}}=137.9 \mathrm{ppm}\right), \mathrm{C}-5\left(\delta_{\mathrm{C}}=138.5 \mathrm{ppm}\right)$ and C-3 $\left(\delta_{\mathrm{C}}=155.3 \mathrm{ppm}\right)$ and coupling at ${ }^{2} \mathrm{JCH}$ (blue) between $\mathrm{H}-1^{\prime}$ and $\mathrm{C}-4\left(\delta_{\mathrm{C}}=117.9 \mathrm{ppm}\right)$ and $\mathrm{C}-2^{\prime}\left(\delta_{\mathrm{C}}=122.4 \mathrm{ppm}\right)$.

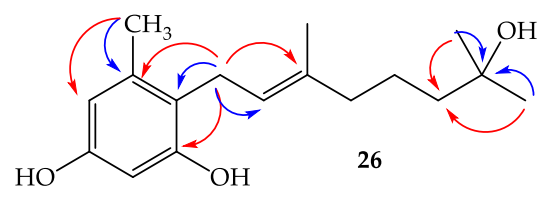

Figure 6. Main heteronuclear correlations $2 \mathrm{D}$ HMBC at ${ }^{2} \mathrm{JCH}$ (blue) and ${ }^{3} \mathrm{JCH}$ (red) observed for compound 26.

Figure 7 shows ${ }^{1} \mathrm{H}-\mathrm{NMR}$ spectra of geranylated orcinol and mono-hydrated and dehydrated derivatives obtained as products of reactions described in Schemes 1 and 2. Signals due to $\mathrm{H}$ atoms involved in the hydration reaction are clearly depicted to demonstrate the attaching of hydroxyl groups to one or both double bonds.
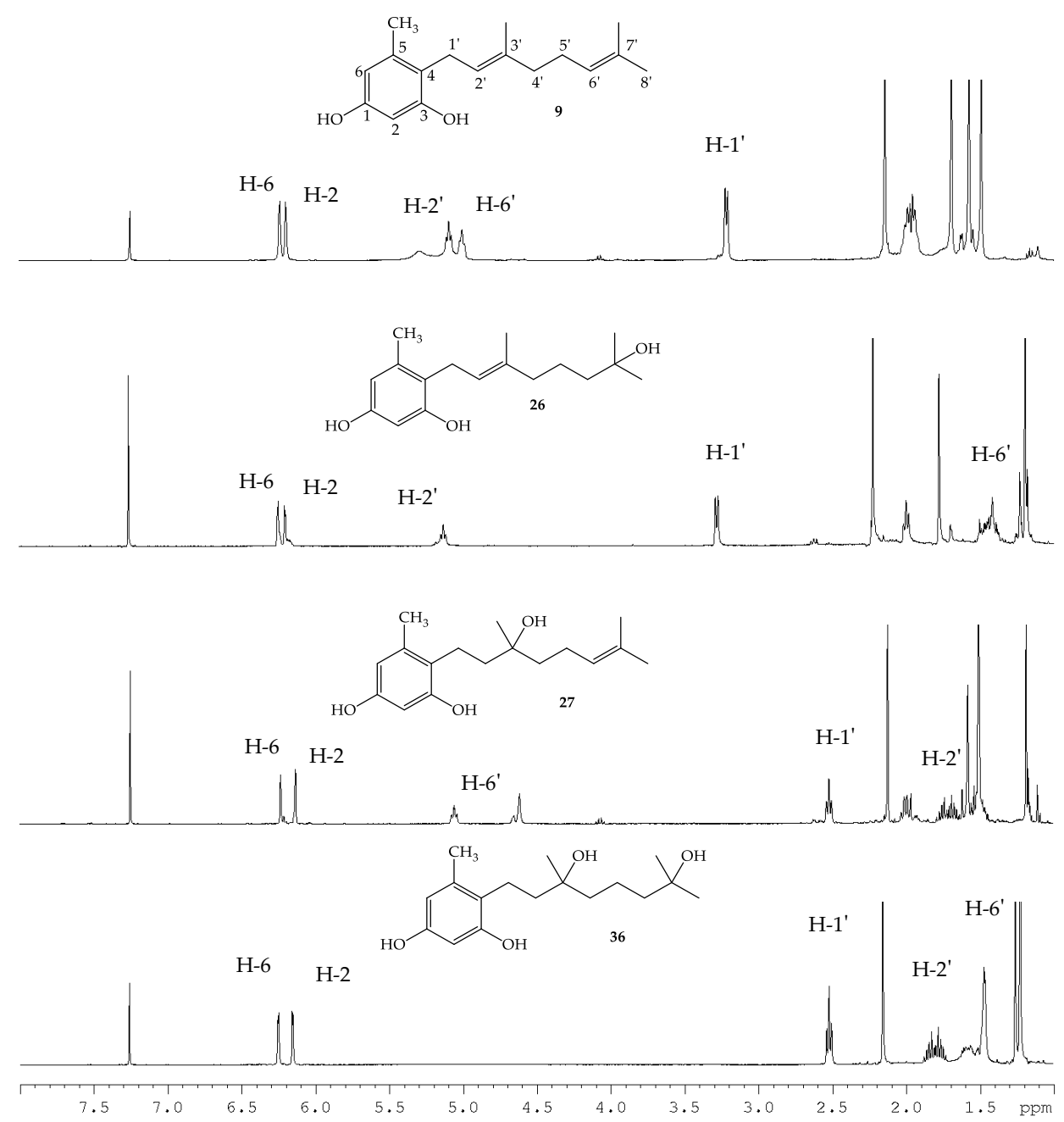

Figure 7. Comparison between ${ }^{1} \mathrm{H}-\mathrm{NMR}$ spectra of geranylated orcinol derivatives 9, 26, 27 and 36 . 
The main signals of orcinol in the ${ }^{1} \mathrm{H}-\mathrm{NMR}$ spectrum appear at $\delta=3.28(2 \mathrm{H}, d$, $J=6.7 \mathrm{~Hz}), \delta=5.14(1 \mathrm{H}, \mathrm{m}) ; 5.04(1 \mathrm{H}, \mathrm{m})$ assigned to $\mathrm{H}-1^{\prime} ; \mathrm{H}-2^{\prime}$ and $\mathrm{H}-6^{\prime}$, respectively. In the mono-hydrated compound $\mathbf{2 6}$, these signals appear with the same chemical shift, excepting $\mathrm{H}-6^{\prime}$ that is shifted to the lower field, $\delta=1.80(2 \mathrm{H}, \mathrm{m})$, due to the interaction with the hydroxyl group. A similar effect is observed for $\mathrm{H}-2^{\prime}$ in compound 27 , whereas in the spectra of compound 36 signals corresponding to $\mathrm{H}-1^{\prime} ; \mathrm{H}-2^{\prime}$ and $\mathrm{H}-6^{\prime}$ appear at $\delta=2.52$ $(2 \mathrm{H}, \mathrm{t}, J=6.68 \mathrm{~Hz}) ; 1.80(2 \mathrm{H}, \mathrm{m})$ y $1.47(2 \mathrm{H}, \mathrm{m})$, respectively.

\subsection{In Vitro Antifungal Activity against B. cinerea}

The inhibition of mycelial growth of $B$. cinerea by all geranylated phenols, with and without hydrated side chain, was evaluated by measuring colony diameters in the presence and absence of tested compounds at different concentrations. Typical results obtained for derivative $\mathbf{3 0}$ are shown in Figure 8. The mycelial growth in the presence of three different concentrations was measured and compared with those observed in the absence of any growth inhibitor (negative control) and in presence of a commercial fungicide (BC-1000, positive control).
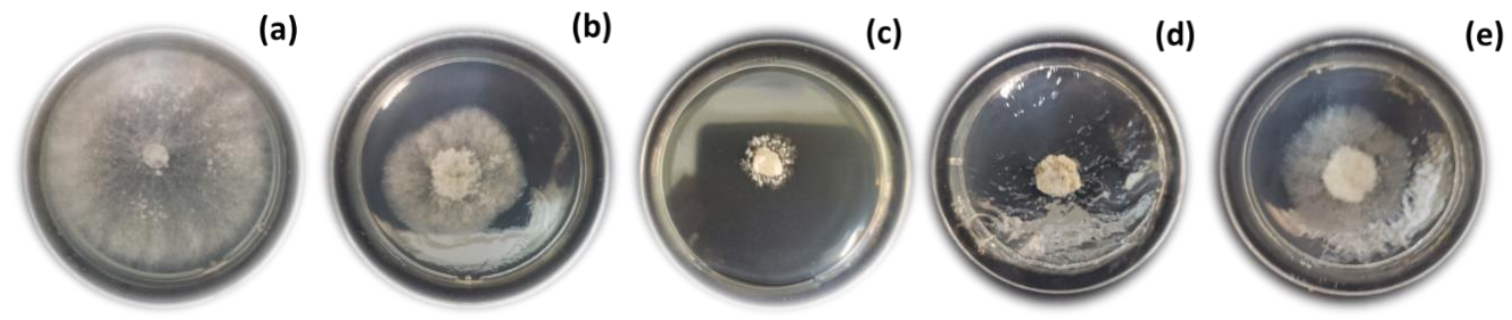

Figure 8. In vitro effect of geranylated phenols with one hydroxyl group in the side chain (30) on mycelial growth of Botrytis cinerea at different concentrations: (a) $0 \mu \mathrm{g} / \mathrm{mL}$ (Negative control); (b) $10 \mu \mathrm{g} / \mathrm{mL}$; (c) $150 \mu \mathrm{g} / \mathrm{mL}$; (d) $250 \mu \mathrm{g} / \mathrm{mL}$; (e) BC-1000 at $150 \mu \mathrm{g} / \mathrm{mL}$, used as positive control.

From these results the percentage of inhibition was calculated and plotted as a function of concentration for each compound. Finally, fitting data to the response-activity equation provides the $\mathrm{EC}_{50}$ values that are tabulated in Tables 1-3

Table 1. Effect of chemical structure on the growth inhibition activity of geranylated phenols with no hydroxyl groups in the side chain.

\begin{tabular}{cc}
\hline Geranylated Compounds & $\mathbf{E C}_{\mathbf{5 0}}, \boldsymbol{\mu g} / \mathbf{m L} \pm \mathbf{S D}^{\mathbf{a}}$ \\
\hline 3 & $>300(\mathrm{NA})$ \\
16 & $136 \pm 1.56$ \\
17 & $89 \pm 2.00$ \\
18 & $84 \pm 1.84$ \\
19 & $78 \pm 2.45$ \\
20 & $224 \pm 4.56$ \\
21 & $181 \pm 3.62$ \\
22 & $276 \pm 5.80$ \\
\hline
\end{tabular}

a $\mathrm{SD}$, standard deviation.

The biological activity of geranylated phenols with no hydroxyl functions in the side chain (Figure 3) are listed in Table 1.

The data in Table 1 indicate that the highest activity against $B$. cinerea is exhibited by compounds 17, 18 and 19. In all of them the geranyl chain is in the ortho position to the phenol group. Changing the hydroxyl group by a methyl group or moving the geranyl chain to the para position (compounds $\mathbf{1 6}$ and 3, respectively), reduces the inhibition activity. In a previous work it was shown that 2-geranylhydroquinone (compound 18) was the most active of a series of geranylated phenols with two or three hydroxyl groups, and that the activity decreases slightly by acetylation of hydroxyl groups [11]. Herein, compound 
19, with two methoxy groups, exhibits almost the same activity, suggesting that methoxy groups have no effect on activity.

Table 2. Effect of chemical structure on the growth inhibition activity of geranylated phenols with one hydroxyl group in the side chain. Compounds $23,26,28-32$ are hydroxylated in C-7', whereas $24,25,27,33$ have the hydroxyl group in C-3'.

\begin{tabular}{cc}
\hline Geranylated Compounds & EC $_{\mathbf{5 0}}, \boldsymbol{\mu g} / \mathbf{m L} \pm \mathbf{S D}^{\mathbf{a}}$ \\
\hline 23 & $130 \pm 2.25$ \\
24 & $134 \pm 4.30$ \\
25 & $108 \pm 1.70$ \\
26 & $162 \pm 3.24$ \\
27 & $60 \pm 1.20$ \\
28 & $>300$ \\
29 & $217 \pm 6.54$ \\
30 & $17 \pm 1.35$ \\
31 & $>300$ \\
32 & $48 \pm 0.80$ \\
33 & $151 \pm 3.20$ \\
\hline
\end{tabular}

a SD, standard deviation.

Table 3. Effect of chemical structure on the growth inhibition activity of geranylated phenols with two hydroxyl groups in the side chain.

\begin{tabular}{cc}
\hline Geranylated Compounds & $\mathrm{EC}_{\mathbf{5 0}}, \boldsymbol{\mu g} / \mathbf{m L} \pm \mathbf{S D}^{\mathbf{a}}$ \\
\hline $\mathbf{3 4}$ & $>300$ \\
$\mathbf{3 5}$ & $54 \pm 0.75$ \\
$\mathbf{3 6}$ & $>300$ \\
$\mathbf{3 7}$ & $217 \pm 3.46$ \\
$\mathbf{3 8}$ & $123 \pm 2.65$ \\
\hline
\end{tabular}

a SD, standard deviation.

On the other hand, $\mathrm{EC}_{50}$ values obtained for geranylated phenols with hydrated side chain are listed in Tables 2 and 3.

The data show that the effect of side chain hydration on bioactivity depends strongly on the structure of geranylated phenols. For example, the position of -OH in monohydrated compounds 23 and 24 has almost no effect on $\mathrm{EC}_{50}$ values, whereas compound $27(-\mathrm{OH}$ in $\left.\mathrm{C}-3^{\prime}\right)$ is three times more active than $26\left(-\mathrm{OH}\right.$ in $\left.\mathrm{C}-7^{\prime}\right)$. On the other hand, hydration in the $C-3^{\prime}$ slightly diminishes the bioactivity from 84 (compound 18) to 108 (compound 25), whereas hydration in $\mathrm{C}-7^{\prime}$ of compound 19 leads to compound $\mathbf{3 0}$ which is the most active geranyl derivative reported in this work. This structural change induces a five-fold change in the $\mathrm{EC}_{50}$ value. Finally, addition of a second hydroxyl group decreases the activity at a level that some of them are completely inactive (compares $\mathrm{EC}_{50}$ values of compounds 23 , 24 and 34; 26, 27 and 36). The exception is compound 35 that exhibits higher activity than 25 , i.e., $\mathrm{EC}_{50}$ values of 54 and 108, respectively.

To get a better insight in the way that growth inhibition activity depends on the chemical structure of the geranylated phenols, and specially the hydration of the side alkyl chain, we have performed a docking molecular study.

\subsection{Molecular Docking Study}

Recently, it has been shown that the antifungal activity of a variety of compounds is mainly due to inhibition of succinate dehydrogenase (SDH) which is a component of the mitochondrial respiratory chain and the tricarboxylic acid cycle [21-23]. Thus, the interactions of antifungal compounds with the ubiquinone binding site have been evaluated to understand the experimental activity shown by different series of related compounds [24-28]. In this work, we have performed molecular docking studies of geranylated phenols carrying one (23-33), two $(34-38)$ or no $(14,18,19)$ hydroxyl groups in 
the side alkyl chain. Molecular coupling of these compounds to a single crystal structure of $\mathrm{SDH}$ (PDB code 2FBW) was carried out by using Glide software. The obtained data indicate that binding energies of these compounds to the allosteric binding site of $\mathrm{SDH}$ are in the range of -9.2 to $-5.4 \mathrm{kcal} \mathrm{mol}^{-1}$ (Table 4). Interestingly, the most active compounds (lowest $\mathrm{EC}_{50}$ values) give the highest docking scores. For example, the most active geranylated phenols with one $-\mathrm{OH}$ in the geranyl chain are compounds 30,32 and 27 , which give the highest binding energies, namely -9.2 to -7.6 . The same trend is obtained for di-hydrated compounds, 37 and 35, and compounds with no-OH in the geranyl chain, 19 and 18. In a previous study, we evaluated the antifungal activity of a series of geranylated phenols, geranylated quinones and hydrated-geranyl phenols. The results indicated that compound 14 was the most active compound and at least two times more active than the dihydrated derivative 13 [14]. Therefore, 14 was included in the molecular docking study and a docking score of $-8.9 \mathrm{kcal} \mathrm{mol}^{-1}$ was obtained, which is very close to that obtained for compound 30.

Table 4. Binding energies, obtained from molecular docking studies and antifungal activities against B. cinerea (EC 50 values) of geranylated phenols with one $(14,23-33)$, two $(34-38)$ or none $(18,19,21)$ hydroxyl groups in the side alkyl chain. CBE is used for comparison ${ }^{1}$.

\begin{tabular}{|c|c|c|c|c|c|c|c|c|}
\hline \multicolumn{3}{|c|}{ One Hydroxyl Group } & \multicolumn{3}{|c|}{ Two Hydroxyl Group } & \multicolumn{3}{|c|}{ No Hydroxyl Group } \\
\hline ID & $\begin{array}{r}\mathrm{EC}_{50} \\
\mu \mathrm{g} / \mathrm{mL}\end{array}$ & $\begin{array}{l}\text { Docking } \\
\text { Score }\end{array}$ & ID & $\begin{array}{r}\mathrm{EC}_{50} \\
\mu \mathrm{g} / \mathrm{mL}\end{array}$ & $\begin{array}{l}\text { Docking } \\
\text { Score }\end{array}$ & ID & $\begin{array}{r}\mathrm{EC}_{50} \\
\mu \mathrm{g} / \mathrm{mL}\end{array}$ & $\begin{array}{l}\text { Docking } \\
\text { Score }\end{array}$ \\
\hline 30 & 17 & -9.2 & 37 & 217 & -7.4 & 19 & 78 & -8.1 \\
\hline 14 & - & -8.9 & 35 & 54 & -7.0 & 18 & 84 & $-7,1$ \\
\hline 32 & 48 & -8.8 & 38 & 123 & -6.7 & 21 & 181 & -6.9 \\
\hline 27 & 60 & -7.6 & 34 & $>300$ & -6.3 & 20 & 224 & -5.4 \\
\hline 25 & 108 & -6.9 & 36 & $>300$ & -6.2 & & & \\
\hline 24 & 134 & -6.8 & & & & & & \\
\hline 26 & 162 & -6.8 & & & & & & \\
\hline 29 & 217 & -6.5 & & & & & & \\
\hline 33 & 151 & -6.4 & & & & & & \\
\hline 28 & $>300$ & -6.1 & & & & & & \\
\hline 23 & 130 & -6.0 & & & & & & \\
\hline 31 & $>300$ & -5.6 & & & & & & \\
\hline
\end{tabular}

${ }^{1}$ CBE: 2-methyl-n-phenyl-5,6-dihydro-1,4-oxathiine-3-carboxamide, ligand crystalized in SDH (2FBW). Docking score: -7.2 .

In the predicted pose of 30, the most active compound, five H-bonds were identified. Two of them are formed by the hydroxyl group in position 4 with Tyr 58 and Trp 173 at $1.98 \AA$ and $2.17 \AA$, respectively; the others are formed by interaction between the hydroxyl group in position 1 and Ser 39 at $1.91 \AA$; the methoxy group at position 5 and Trp 173 at $2.05 \AA$; the hydroxyl group at $C 7^{\prime}$ and Tyr 58 . The latter is mediated by a water molecule located at $1.84 \AA$ from the hydroxyl group and $2.18 \AA$ from the Tyr 58 residue (see Figure 9). On the other hand, the side alkyl chain participates in van der Waals interactions with Pro 169, Ile 27, Ile 40, Ile 218, Trp 32, Trp 172, Hie 216, Arg 43 and Met 36.

It seems that hydroxyl groups in positions 1 and 4 and in the alkyl side chain play a main role in the binding of compounds to the active site, and consequently in the antifungal activity [29]. For example, compounds $\mathbf{1 4}$ and $\mathbf{2 9}$ differ only in the nature of substituent at position 4, i.e., $-\mathrm{OH}$ in compound $\mathbf{1 4}$ and $-\mathrm{OCH}_{3}$ in 29 and the docking scores are completely different: -8.9 and -6.5 , respectively. To address the binding mode, three compounds exhibiting different antifungal activities were tested and the interactions with amino acid residues in the SDH active site were determined (Figure 10). 


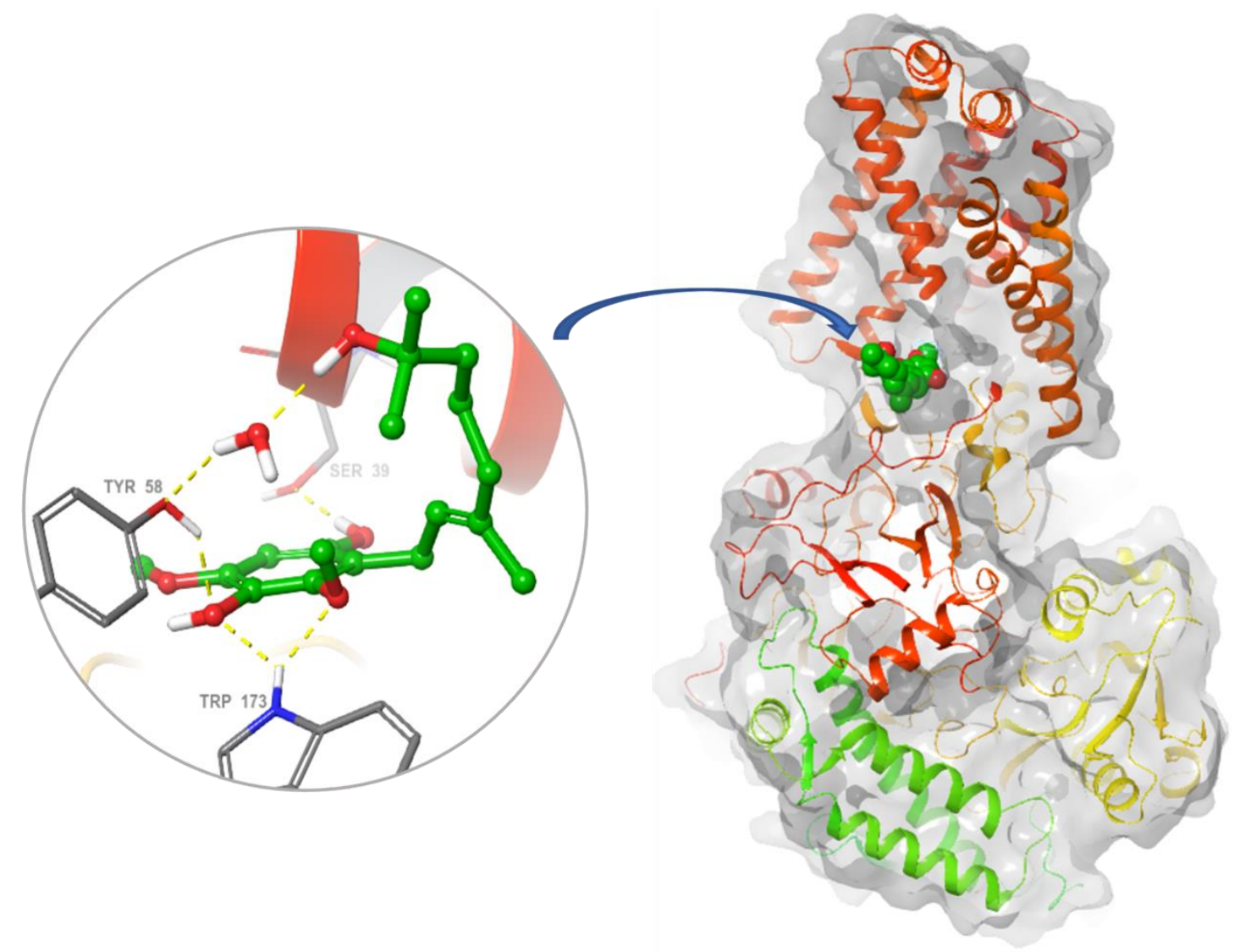

Figure 9. Predicted binding mode of 30 into the allosteric site of enzyme SDH (PDB 2FBW). Hydrogen bonds are represented as yellow dotted lines. (Image created using Maestro 11.8).

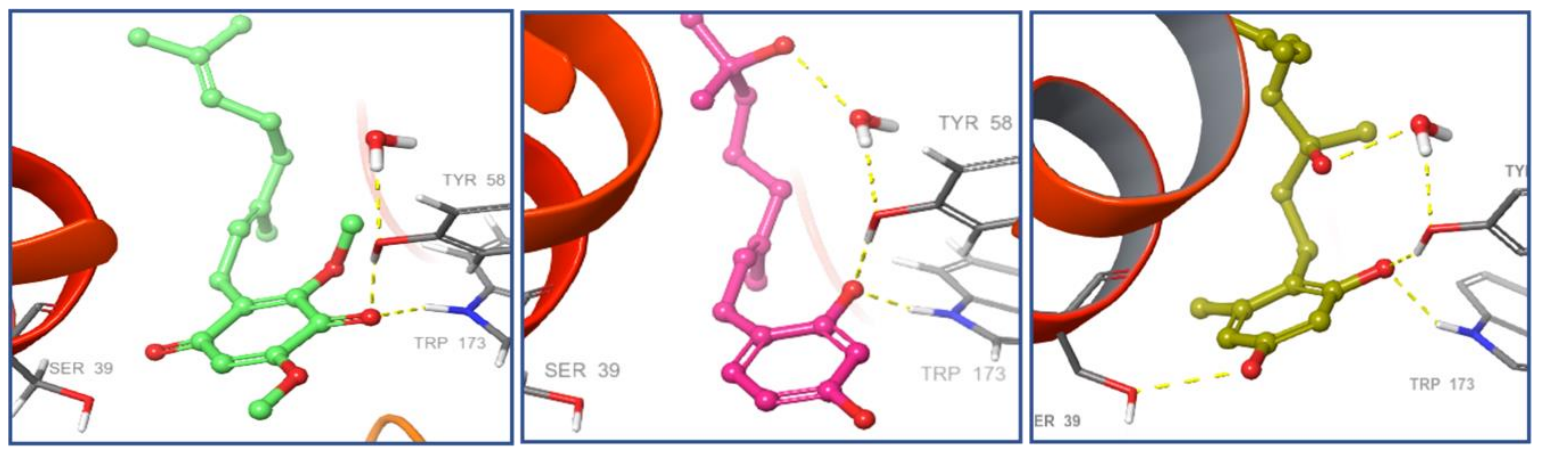

Figure 10. Predicted binding mode of 20, 23 and 27 into the allosteric site of enzyme SDH (PDB 2FBW). (Image created using Maestro 11.8).

The results indicate that the experimental antifungal activity correlates with the number of H-bonds formed, i.e., compound 20 (low activity, $\mathrm{EC}_{50}=224 \mu \mathrm{g} / \mathrm{mL}$ ) forms two H-bonds, Tyr 58 and Trp 173; compound 23 (medium activity, $\mathrm{EC}_{50}=130 \mu \mathrm{g} / \mathrm{mL}$ ) forms three H-bonds, Trp 173 and two with Tyr 58; compound 27 (high activity, $\mathrm{EC}_{50}=59 \mu \mathrm{g} / \mathrm{mL}$ ) forms four H-bonds, Ser 39, Trp 173 and two with Tyr 58. Thus, it can be concluded that functional groups with $\mathrm{H}$-bond forming atoms, both in the aromatic ring and side alkyl chain, favor the binding of compounds to the allosteric site of SDH and consequently enhance their antifungal activity. 


\section{Materials and Methods}

\subsection{Chemistry}

All chemicals were obtained from Merck (Darmstad, Germany) or Aldrich (St. Louis, MO, USA) and used without further purification. The ${ }^{1} \mathrm{H}$ and ${ }^{13} \mathrm{C}$ NMR spectra were recorded on a Bruker Avance 400 Digital NMR spectrometer, operating at $400.1 \mathrm{MHz}$ for ${ }^{1} \mathrm{H}$ and $100.6 \mathrm{MHz}$ for ${ }^{13} \mathrm{C}$. Samples were prepared in $\mathrm{CDCl}_{3}$ and chemical shifts are reported in $\delta \mathrm{ppm}$, whereas coupling constants $(\mathrm{J})$ are given in $\mathrm{Hz}$. All signals were referenced to the residual peak of $\mathrm{CHCl}_{3}$ at $\delta=7.26 \mathrm{ppm}$ and $\delta=77.00 \mathrm{ppm}$ for ${ }^{1} \mathrm{H}$ and ${ }^{13} \mathrm{C}$, respectively. Lowresolution mass spectra were obtained on a VG Micromass ZAB-2F and high-resolution mass spectra on a VG Micromass ZAB-2F at $70 \mathrm{eV}$. Pure compounds were isolated from product reaction by column chromatography (CC), using silica gel (Merck 200-300 mesh). On the other hand, the degree of reaction was tested by thin layer chromatography (TLC) and using silica gel plates (HF-254). Spots were detected on TLC by heating after spraying with $\mathrm{H}_{2} \mathrm{SO}_{4}\left(25 \%\right.$ in $\left.\mathrm{H}_{2} \mathrm{O}\right)$. Microwave syntheses were carried out in a microwave reactor (Monowave 200, Anton Parr, Graz, Austria) using sealed glass microwave containers with polyether ether ketone (PEEK) lids (capacity 10 or $30 \mathrm{~mL}$ ).

\subsection{Synthesis}

\subsubsection{Microwave-Assisted Electrophilic Aromatic Substitution Reaction}

Coupling of geraniol and substituted phenols was carried out in presence of $\mathrm{BF}_{3} \cdot \mathrm{OEt}_{2}$ as catalyst, acetonitrile as solvent and under microwave radiation. In a typical reaction, a phenol is dissolved in acetonitrile and then an excess of geraniol is added under constant stirring. Once the mixture is homogeneous, it is located into a microwave reactor at $75{ }^{\circ} \mathrm{C}$ and $40 \mathrm{~W}$ of power is applied for $10 \mathrm{~min}$. At the end of this period, the power is switched off and the temperature decreased to $40{ }^{\circ} \mathrm{C}$. The reacted mixture is slowly added to water $(20 \mathrm{~mL})$ and then extracted with ethyl acetate (EtOAc). The organic phase was washed with aqueous $\mathrm{NaHCO}_{3}$ solution $(10 \%, 20 \mathrm{~mL})$ and water $(3$ times, $20 \mathrm{~mL})$, dried over $\mathrm{MgSO}_{4}$ and concentrated by reduced pressure distillation. Pure compounds were obtained by column chromatography using hexane/EtOAc mixtures of increasing polarity.

(E)-4-(3,7-dimethylocta-2,6-dien-1-yl)-6-methylphenol (3)

Compound 3 was obtained by microwave-assisted coupling reaction of $o$-cresol $(1 \mathrm{~g}$, $9.3 \mathrm{mmol}$ ) and geraniol $(3.0 \mathrm{~g}, 19.0 \mathrm{mmol})$. Compound 3 ( $497 \mathrm{mg}$, 22\% yield) was obtained as a brown viscous oil. Spectroscopic data obtained for 3 were consistent with those previously reported [14].

(E)-2-(3,7-dimethylocta-2,6-dien-1-yl)benzene-1,4-diol (18)

Compound 18 was obtained by a microwave-assisted electrophilic aromatic substitution reaction, from hydroquinone $(1 \mathrm{~g}, 9.0 \mathrm{mmol})$ and geraniol $(2.2 \mathrm{~g}, 14.2 \mathrm{mmol})$. The compound 18 was obtained as a brown viscous oil ( $470 \mathrm{mg}, 21 \%$ yield). Spectroscopic data of $\mathbf{1 8}$ were consistent with those previously reported [9].

\section{(E)-2-(3,7-dimethylocta-2,6-dien-1-yl)benzene-1,3,5-triol (22)}

Compound 22 was obtained by a microwave-assisted electrophilic aromatic substitution reaction, from phloroglucinol $(1 \mathrm{~g}, 7.9 \mathrm{mmol})$ and geraniol $(3 \mathrm{~g}, 19.5 \mathrm{mmol})$, as a brown viscous oil ( $416 \mathrm{mg}, 20 \%$ yield). Spectroscopic data for 22 were consistent with those previously reported [11].

(E)-4-(3,7-dimethylocta-2,6-dien-1-yl)-3-methylphenol (16) and

(E)-2-(3,7-dimethylocta-2,6-dien-1-yl)-5-methylphenol (17)

Microwave-assisted electrophilic aromatic substitution reaction of $m$-cresol $(1 \mathrm{~g}, 9.3 \mathrm{mmol})$ and geraniol $(3.0 \mathrm{~g}, 19.0 \mathrm{mmol})$ gives a reaction product from which two fractions were obtained by C.C. Fraction I: Compound 16 ( $226 \mathrm{mg}, 10 \%$ yield) obtained as a brown viscous oil and Fraction II: Compound 17 (497 mg, 22\% yield) obtained as a brown viscous 
oil. Spectroscopic data recorded for compounds 16 and 17 were consistent with those previously reported [30].

(E)-2-(3,7-dimethylocta-2,6-dien-1-yl)-4,5-dimethoxyphenol (21)

Compound 21 was obtained by microwave-assisted electrophilic aromatic substitution reaction, from 3,4-dimethoxyphenol (2 g, $12.9 \mathrm{mmol})$ and geraniol (4.5 g, $29.2 \mathrm{mmol})$. Compound 21 was obtained as a brown viscous oil ( $827 \mathrm{mg}, 22 \%$ yield), and its spectroscopic data were consistent with those previously reported [30].

(E)-2-(3,7-dimethylocta-2,6-dien-1-yl)-3,5-dimethoxybenzene-1,4-diol (19)

Compound 19 was obtained by a microwave-assisted electrophilic aromatic substitution reaction, from 2,6-dimethoxyhydroquinone $(1 \mathrm{~g}, 5.9 \mathrm{mmol})$ and geraniol $(2.2 \mathrm{~g}$, $14.2 \mathrm{mmol})$, as a brown viscous oil (396 mg, 21\% yield). Compound 19: ${ }^{1} \mathrm{H}$ NMR (400 MHz, $\mathrm{CDCl}_{3}$ ) (Figure S1, Supplementary Material): $\delta 5.93$ (s, 1H, H-6); $5.04\left(\mathrm{~m}, 2 \mathrm{H}, \mathrm{H}-2^{\prime}\right.$ y H-6'), 3.96 (s, 3H, $\left.\mathrm{CH}_{3} \mathrm{O}-\mathrm{C} 3\right) ; 3.79$ (s, 3H, $\left.\mathrm{CH}_{3} \mathrm{O}-\mathrm{C} 5\right) ; 3.15$ (d, J = 7.3 Hz, 2H, H-1'); 2.03 (m, 2H, $\left.\mathrm{H}-5^{\prime}\right) ; 1.95$ (m, 2H, H-4 $\left.{ }^{\prime}\right) ; 1.72$ (s, 3H, $\left.\mathrm{CH}_{3}-\mathrm{C}^{\prime}\right)$; 1.65 (s, 3H, H-8 $) ; 1.57$ (s, 3H, $\left.\mathrm{CH}_{3}-\mathrm{C}^{\prime}\right) .{ }^{13} \mathrm{C}$ NMR (100 MHz, $\left(\mathrm{CDCl}_{3}\right)$ (Figure S1, Supplementary Material): $\delta 157.2$ (C-1); 154.1 (C-3); 150.2 (C-5); 137.3 (C-3'); 132.9 (C-7'); $131.4\left({\left.\mathrm{C}-6^{\prime}\right)}^{\prime} 124.1\right.$ (C-2'); 128.3 (C-4); 119.7 (C-2); 106.9

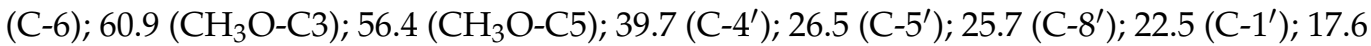
$\left(\mathrm{CH}_{3}-\mathrm{C}^{\prime}\right) ; 16.1\left(\mathrm{CH}_{3}-\mathrm{C}^{\prime}\right)$. EIMS m/z: $306\left[\mathrm{M}^{+}\right]$(12), 69 (57), 118 (30), 123 (27), 169 (29), 177 (41), 182 (65), 221 (100), 235 (47), 261 (45), 304 (35); HR-EIMS [M+] found 306.1841, calcd for $\mathrm{C}_{18} \mathrm{H}_{26} \mathrm{O}_{4} 306.1831$ (Figure S18, Supplementary Material).

\subsubsection{Hydration Reaction}

Hydration reactions were performed by dissolving geranylated phenols in dioxane (20-40 mL) containing water (5-7 mL) and using $p$-toluenesulfonic acid polymer-bound as catalyst PTSA-PB (macroporous polymer, 30-60 mesh, 2.0-3.0 mmol/g loading, Aldrich). The reaction mixture is refluxed with constant stirring until no reaction is detected by TLC (16 to $24 \mathrm{~h}$ ). The crude reaction product was extracted with AcOEt and the organic phase was washed with aqueous $\mathrm{NaHCO}_{3}$ solution $(10 \%, 10-20 \mathrm{~mL})$ and water (2 times, $\left.20 \mathrm{~mL}\right)$, dried over $\mathrm{MgSO}_{4}$ and concentrated by reduced pressure distillation. Pure compounds were obtained by column chromatography using hexane/EtOAc mixtures of increasing polarity.

4-(3-hydroxy-3,7-dimethyloct-6-en-1-yl)benzene-1,3-diol (24);

(E)-4-(7-hydroxy-3,7-dimethyloct-2-en-1-yl)benzene-1,3-diol (23) and

4-(3,7-dihydroxy-3,7-dimethyloctyl)benzene-1,3-diol (34)

Compounds 23, 24 and 34 were obtained from 4-geranylresorcinol (300 mg, $1.2 \mathrm{mmol})$ and PTSA-PB (500 mg, $\approx 1.5 \mathrm{mmol})$ in dioxane $(20 \mathrm{~mL})$ with $\mathrm{H}_{2} \mathrm{O}(5 \mathrm{~mL})$. Three fractions were obtained from C.C. Fraction I: Compound 24 (29 mg, 9\% yield) obtained as a brown viscous oil. ${ }^{1} \mathrm{H}$ NMR (400 MHz, $\mathrm{CDCl}_{3}$ ) (Figure S4, Supplementary Material): $6.88(d$, $J=8.6 \mathrm{~Hz}, 1 \mathrm{H}, \mathrm{H}-5), 6.32(\mathrm{~m}, 2 \mathrm{H}, \mathrm{H}-2, \mathrm{H}-6), 5.11\left(\mathrm{~m}, 1 \mathrm{H}, \mathrm{H}-6^{\prime}\right), 2.61$ (m, 2H, H-1'), 2.08 (m, $\left.2 \mathrm{H}, \mathrm{H}-5^{\prime}\right), 1.80\left(\mathrm{~m}, 2 \mathrm{H}, \mathrm{H}-2^{\prime}\right), 1.60\left(\mathrm{~m}, 2 \mathrm{H}, \mathrm{H}-4^{\prime}\right) 1.67$ (s, 3H, H-8 $), 1.60$ (s, 3H, $\left.\mathrm{CH}_{3}-\mathrm{C}^{\prime}\right)$, $1.28\left(\mathrm{~s}, 3 \mathrm{H}, \mathrm{CH}_{3}-\mathrm{C}^{\prime}\right) .{ }^{13} \mathrm{C}$ NMR $\left(100 \mathrm{MHz},\left(\mathrm{CDCl}_{3}\right)\right.$ (Figure S4, Supplementary Material): $\delta$

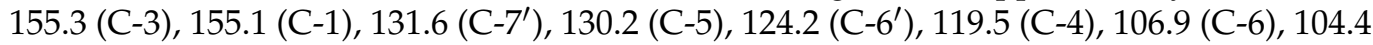
(C-2), $75.4\left(\mathrm{C}-3^{\prime}\right), 39.3\left(\mathrm{C}-4^{\prime}\right), 30.6\left(\mathrm{C}-2^{\prime}\right), 25.7\left(\mathrm{C}-8^{\prime}\right), 24.0\left(\mathrm{CH}_{3}-\mathrm{C}^{\prime}\right), 22.3\left(\mathrm{C}-5^{\prime}\right), 21.1\left(\mathrm{C}-1^{\prime}\right)$, $17.6\left(\mathrm{CH}_{3}-\mathrm{C} 5\right), 16.3\left(\mathrm{CH}_{3}-\mathrm{C}^{\prime}\right)$. EIMS m/z: 246 [M+- $\left.\mathrm{M}_{2} \mathrm{O}\right]$ (23), 123 (100), 161 (31), 163 (11), 177 (8); HR-EIMS [ $\mathrm{M}^{+}-\mathrm{H}_{2} \mathrm{O}$ ] found 246.1627, calcd for $\mathrm{C}_{16} \mathrm{H}_{22} \mathrm{O}_{2} 246.1620$ (Figure S21, Supplementary Material). Fraction II: Compound 34 (35 mg, 10\% yield) obtained as a brown viscous oil. ${ }^{1} \mathrm{H}$ NMR $\left(400 \mathrm{MHz} \mathrm{CDCl}_{3}\right)$ (Figure S13, Supplementary Material): $\delta$ $6.89(d, J=8.2 \mathrm{~Hz}, 1 \mathrm{H}, \mathrm{H}-5), 6.34(d, J=8.2 \mathrm{~Hz}, 1 \mathrm{H}, \mathrm{H}-2), 6.27(\mathrm{~s}, 1 \mathrm{H}, \mathrm{H}-6), 2.66(\mathrm{~m}, 2 \mathrm{H}$, $\left.\mathrm{H}-1^{\prime}\right), 1.78\left(\mathrm{~m}, 4 \mathrm{H}, \mathrm{H}-2^{\prime}, \mathrm{H}-4^{\prime}\right), 1.54\left(\mathrm{~m}, 4 \mathrm{H}, \mathrm{H}-5^{\prime}, \mathrm{H}-6^{\prime}\right), 1.27\left(\mathrm{~s}, 3 \mathrm{H}, \mathrm{CH}_{3}-\mathrm{C}^{\prime}\right), 1.23(\mathrm{~s}, 6 \mathrm{H}$, $\left.\mathrm{H}-8^{\prime}, \mathrm{CH}_{3}-\mathrm{C}^{\prime}\right) .{ }^{13} \mathrm{C} \mathrm{NMR}\left(100 \mathrm{MHz},\left(\mathrm{CDCl}_{3}\right)\right.$ (Figure S13, Supplementary Material): $\delta$ 155.2 (C-1), 154.8 (C-3), 130.2 (C-5), 113.4 (C-4), 107.5 (C-6), 103.9 (C-2), 76.4 (C-3'), 71.5 $\left(\mathrm{C}-7^{\prime}\right), 44.3\left(\mathrm{C}-6^{\prime}\right), 40.3\left(\mathrm{C}-4^{\prime}\right), 31.1\left(\mathrm{C}-2^{\prime}\right), 29.3\left(\mathrm{CH}_{3}-\mathrm{C}^{\prime}\right), 29.3\left(\mathrm{C}-8^{\prime}\right), 24.1\left(\mathrm{CH}_{3}-\mathrm{C}^{\prime}\right), 21.4$ 
(C-1'), 18.3 (C-5'). EIMS m/z: 264 [M $\mathrm{M}^{+}-\mathrm{H}_{2} \mathrm{O}$ ] (15), 123 (100), 161 (12), 163 (14), 175 (9), 177 (5); HREIMS [ $\mathrm{M}^{+}-\mathrm{H}_{2} \mathrm{O}$ ] found 264.1723, calcd for $\mathrm{C}_{16} \mathrm{H}_{24} \mathrm{O}_{3} 264.1725$ (Figure S30, Supplementary Material). Fraction III: Compound $23(26 \mathrm{mg}$, 8\% yield) obtained as a brown viscous oil. ${ }^{1} \mathrm{H}$ NMR (400 MHz, $\mathrm{CDCl}_{3}$ ) (Figure S3, Supplementary Material): $\delta$ $6.92(d, J=8.6 \mathrm{~Hz}, 1 \mathrm{H}, \mathrm{H}-5), 6.34(\mathrm{~m}, 2 \mathrm{H}, \mathrm{H}-2, \mathrm{H}-6), 5.29\left(\mathrm{t}, J=7.3 \mathrm{~Hz}, 1 \mathrm{H}, \mathrm{H}-2^{\prime}\right), 3.28(d$, $\left.J=7.2 \mathrm{~Hz}, 2 \mathrm{H}, \mathrm{H}-1^{\prime}\right), 2.03\left(\mathrm{t}, J=6.9 \mathrm{~Hz}, 2 \mathrm{H}, \mathrm{H}-6^{\prime}\right), 1.74\left(\mathrm{~s}, 3 \mathrm{H}, \mathrm{CH}_{3}-\mathrm{C}^{\prime}\right), 1.47\left(\mathrm{~m}, 4 \mathrm{H}, \mathrm{H}-4^{\prime}\right.$, $\left.\mathrm{H}-5^{\prime}\right), 1.21\left(\mathrm{~s}, 6 \mathrm{H}, \mathrm{H}-8^{\prime}, \mathrm{CH}_{3}-\mathrm{C}^{\prime}\right) .{ }^{13} \mathrm{C}$ NMR $\left(100 \mathrm{MHz},\left(\mathrm{CDCl}_{3}\right)\right.$ (Figure $\mathrm{S} 3$, Supplementary Material): $\delta 155.4$ (C-1), 155.4 (C-3), 137.8 (C-3'), 130.6 (C-5), 122.5 (C-2'), 119.1 (C-4), 107.5 (C-6), $103.3(\mathrm{C}-2), 71.4\left(\mathrm{C}-7^{\prime}\right), 43.2\left(\mathrm{C}-6^{\prime}\right), 39.9\left(\mathrm{C}-4^{\prime}\right), 29.2\left(\mathrm{C}-8^{\prime}\right.$ y $\left.\mathrm{CH}_{3}-\mathrm{C}^{\prime}\right), 29.1\left(\mathrm{C}-1^{\prime}\right), 22.4$ $\left(\mathrm{C}-5^{\prime}\right), 16.1\left(\mathrm{CH}_{3}-\mathrm{C}^{\prime}\right)$. EIMS $m / z(\%): 264\left[\mathrm{M}^{+}\right.$(3), 123 (100), 161 (25), 163 (15), 175 (18), 177 (12), 246 (15); HREIMS [M] ${ }^{+}$found 264.1724, calcd for $\mathrm{C}_{16} \mathrm{H}_{24} \mathrm{O}_{3} 264.1725$ (Figure S20, Supplementary Material).

(E)-2-(3,7-dimethylocta-2,6-dien-1-yl)-3,5-dimethoxycyclohexa-2,5-diene-1,4-dione (20) and (E)-2-(7-hydroxy-3,7-dimethyloct-2-en-1-yl)-3,5-dimethoxycyclohexa-2,5-diene-1,4-dione (31)

Compounds 20 and $\mathbf{3 1}$ were obtained by hydration reaction of 3-geranyl-2,4,6-trimetho xyphenol $(300 \mathrm{mg}, 1.2 \mathrm{mmol})$ in dioxane $(40 \mathrm{~mL})$ with $7 \mathrm{~mL}$ of $\mathrm{H}_{2} \mathrm{O}(7 \mathrm{~mL})$ and PTSA-PB $(700 \mathrm{mg}, 3.5 \mathrm{mmol})$. Two fractions were obtained from the C.C. Fraction I: Compound 20 (122 mg, 32\% yield) obtained as a brown viscous oil. ${ }^{1} \mathrm{H} \mathrm{NMR}\left(400 \mathrm{MHz}, \mathrm{CDCl}_{3}\right)$ (Figure S2, Supplementary Material): $\delta 5.83$ (s, 1H, H-6); 5.05 (m, 2H, H-2' y H-6'), $3.96\left(\mathrm{~s}, 3 \mathrm{H}, \mathrm{CH}_{3} \mathrm{O}-\right.$ $\mathrm{C} 3) ; 3.79\left(\mathrm{~s}, 3 \mathrm{H}, \mathrm{CH}_{3} \mathrm{O}-\mathrm{C} 5\right) ; 3.15\left(d, J=7.3 \mathrm{~Hz}, 2 \mathrm{H}, \mathrm{H}-1^{\prime}\right) ; 2.03\left(\mathrm{~m}, 2 \mathrm{H}, \mathrm{H}-5^{\prime}\right) ; 1.96(\mathrm{~m}, 2 \mathrm{H}$, $\left.\mathrm{H}-4^{\prime}\right) ; 1.72\left(\mathrm{~s}, 3 \mathrm{H}, \mathrm{CH}_{3}-\mathrm{C} 3^{\prime}\right) ; 1.65$ (s, 3H, H-8 $) ; 1.57\left(\mathrm{~s}, 3 \mathrm{H}, \mathrm{CH}_{3}-\mathrm{C}^{\prime}\right) .{ }^{13} \mathrm{C} \mathrm{NMR}(100 \mathrm{MHz}$, $\left(\mathrm{CDCl}_{3}\right)$ (Figure S2, Supplementary Material): $\delta 187.2$ (C-1); 178.4 (C-4); 157.2 (C-5); 154.1 (C-3); $137.3\left(\mathrm{C}-3^{\prime}\right) ; 132.9\left(\mathrm{C}-7^{\prime}\right) ; 124.1\left(\mathrm{C}-6^{\prime}\right) ; 119.7\left(\mathrm{C}-2^{\prime}\right) ; 106.9$ (C-6); $60.9\left(\mathrm{CH}_{3} \mathrm{O}-\mathrm{C} 3\right) ; 56.4$ $\left(\mathrm{CH}_{3} \mathrm{O}-\mathrm{C} 5\right) ; 39.7\left(\mathrm{C}-4^{\prime}\right) ; 26.5\left(\mathrm{C}-5^{\prime}\right) ; 25.7\left(\mathrm{C}-8^{\prime}\right) ; 22.5\left(\mathrm{C}-1^{\prime}\right) ; 17.6\left(\mathrm{CH}_{3}-\mathrm{C}^{\prime}\right) ; 16.1\left(\mathrm{CH}_{3}-\mathrm{C}^{\prime}\right)$. EIMS m/z: 304 [M+'] (32), 123 (34), 183 (85), 194 (17), 221 (100), 235 (32), 26 (33), 289 (15); HR-EIMS [ $\mathrm{M}^{+}$] found 304.1682, calcd for $\mathrm{C}_{18} \mathrm{H}_{24} \mathrm{O}_{4} 304.1675$ (Figure S19, Supplementary Material). Fraction II: Compound 31 ( $28 \mathrm{mg}, 7 \%$ yield) obtained as a brown viscous oil. ${ }^{1} \mathrm{H}$ NMR (400 MHz, CDCl $)$ (Figure S10, Supplementary Material): $\delta 5.83$ (s, 1H, H-6), 5.05 $\left(\mathrm{t}, J=6.8 \mathrm{~Hz}, 1 \mathrm{H}, \mathrm{H}-2^{\prime}\right), 3.96\left(\mathrm{~s}, 3 \mathrm{H}, \mathrm{CH}_{3} \mathrm{O}-\mathrm{C} 3\right), 3.79\left(\mathrm{~s}, 3 \mathrm{H}, \mathrm{CH}_{3} \mathrm{O}-\mathrm{C} 5\right), 3.16(d, J=7.2 \mathrm{~Hz}$, $\left.2 \mathrm{H}, \mathrm{H}-1^{\prime}\right), 1.95\left(\mathrm{~m}, 1 \mathrm{H}, \mathrm{H}-4^{\prime}\right), 1.72\left(\mathrm{~s}, 3 \mathrm{H}, \mathrm{CH}_{3}-\mathrm{C}^{\prime}\right), 1.40\left(\mathrm{~m}, 2 \mathrm{H}, \mathrm{H}-6^{\prime}\right), 1.23\left(\mathrm{~m}, 2 \mathrm{H}, \mathrm{H}-5^{\prime}\right)$, 1.20 (s, 6H, H-8 y CH $\left.3-\mathrm{C}^{\prime}\right) .{ }^{13} \mathrm{C}$ NMR $\left(100 \mathrm{MHz},\left(\mathrm{CDCl}_{3}\right)\right.$ (Figure S10, Supplementary Material): $\delta 187.2$ (C-1), 178.5 (C-4), 157.3 (C-5), 154.1 (C-3), 137.2 (C-3'), 132.8 (C-2'), 119.9 (C-2), 106.9 (C-6), $71.0\left(\mathrm{C}-7^{\prime}\right), 61.0\left(\mathrm{CH}_{3} \mathrm{O}-\mathrm{C} 3\right), 56.4\left(\mathrm{CH}_{3} \mathrm{O}-\mathrm{C} 5\right), 43.4\left(\mathrm{C}-6^{\prime}\right), 40.0\left(\mathrm{C}-4^{\prime}\right), 29.2$ $\left(\mathrm{C}-8^{\prime}\right.$ y $\left.\mathrm{CH}_{3}-\mathrm{C}^{\prime}\right), 22.5\left(\mathrm{C}-1^{\prime}\right.$ y $\left.\mathrm{C}-5^{\prime}\right), 16.1\left(\mathrm{CH}_{3}-\mathrm{C}^{\prime}\right)$. EIMS $m / z$ [M $\left.{ }^{+}\right] 322$ (9), 149 (100), 183 (63), 194 (15), 221 (67), 305 (14); HR-EIMS [ $\mathrm{M}^{+}$] found 322.1783, calcd for $\mathrm{C}_{18} \mathrm{H}_{26} \mathrm{O}_{5} 322.1783$ (Figure S27, Supplementary Material).

(E)-4-(7-hydroxy-3,7-dimethyloct-2-en-1-yl)-5-methylbenzene-1,3-diol (26), 4-(3-hydroxy-3,7-dimethyloct-6-en-1-yl)-5-methylbenzene-1,3-diol (27) and 4-(3,7-dihydroxy-3,7-dimethyloctyl)-5-methylbenzene-1,3-diol (36)

Compounds 26, 27 and 36 were obtained from geranylorcinol $(200 \mathrm{mg}, 0.8 \mathrm{mmol})$ and PTSA-PB ( $400 \mathrm{mg}, 2.0 \mathrm{mmol})$ in dioxane $(30 \mathrm{~mL})$ with $\mathrm{H}_{2} \mathrm{O}(5 \mathrm{~mL})$, following the standard procedure described above for the hydration reaction. Three fractions were obtained by C.C. Fraction I: Compound 27 ( $60 \mathrm{mg}, 28 \%$ yield) obtained as a brown viscous oil. ${ }^{1} \mathrm{H}$ NMR $\left(400 \mathrm{MHz}, \mathrm{CDCl}_{3}\right.$ ) (Figure S6, Supplementary Material): $\delta 6.26(\mathrm{~s}, 1 \mathrm{H}, \mathrm{H}-6), 6.16(\mathrm{~s}, 1 \mathrm{H}$, $\mathrm{H}-2), 5.10\left(\mathrm{~m}, 1 \mathrm{H}, \mathrm{H}-6^{\prime}\right), 4.66(\mathrm{~s}, 1 \mathrm{H}, \mathrm{OH}), 2.60\left(\mathrm{~m}, 2 \mathrm{H}, \mathrm{H}-\mathrm{1}^{\prime}\right), 2.20\left(\mathrm{~s}, 3 \mathrm{H}, \mathrm{CH}_{3}-\mathrm{C} 5\right), 2.08(\mathrm{~m}$, $\left.2 \mathrm{H}, \mathrm{H}-5^{\prime}\right), 1.80\left(\mathrm{~m}, 2 \mathrm{H}, \mathrm{H}-2^{\prime}\right), 1.60\left(\mathrm{~m}, 2 \mathrm{H}, \mathrm{H}-4^{\prime}\right), 1.67\left(\mathrm{~s}, 3 \mathrm{H}, \mathrm{H}-8^{\prime}\right), 1.60\left(\mathrm{~s}, 3 \mathrm{H}, \mathrm{CH}_{3}-\mathrm{C}^{\prime}\right)$, $1.28\left(\mathrm{~s}, 3 \mathrm{H}, \mathrm{CH}_{3}-\mathrm{C}^{\prime}\right) .{ }^{13} \mathrm{C} \mathrm{NMR}\left(100 \mathrm{MHz},\left(\mathrm{CDCl}_{3}\right)\right.$ (Figure $\mathrm{S} 6$, Supplementary Material): $\delta 154.7$ (C-3), 153.6 (C-1), 137.4 (C-5), $131.6\left(\mathrm{C}-7^{\prime}\right), 124.2$ (C-6'), 110.4 (C-4), 106.9 (C-6), 105.4 (C-2), $75.7\left(\mathrm{C}-3^{\prime}\right), 39.3\left(\mathrm{C}-4^{\prime}\right), 30.4\left(\mathrm{C}-2^{\prime}\right), 25.7\left(\mathrm{C}-8^{\prime}\right), 24.0\left(\mathrm{CH}_{3}-\mathrm{C}^{\prime}\right), 22.3\left(\mathrm{C}-5^{\prime}\right), 21.1$ $\left(\mathrm{C}-1^{\prime}\right), 17.6\left(\mathrm{CH}_{3}-\mathrm{C} 5\right), 16.3\left(\mathrm{CH}_{3}-\mathrm{C} 7^{\prime}\right)$. EIMS m/z $260\left[\mathrm{M}^{+}\right]$(31), 123 (11), 137 (100), 175 (26), 177 (12); HR-EIMS $\left[\mathrm{M}^{+}-\mathrm{H}_{2} \mathrm{O}\right.$ ] found 260.1786, calcd for $\mathrm{C}_{17} \mathrm{H}_{24} \mathrm{O}_{2} 260.1776$ (Figure S23, Supplementary Material). Fraction II: Compound 36 (36 mg, 16\% yield) obtained as a 
brown viscous oil. ${ }^{1} \mathrm{H}$ NMR (400 MHz, $\mathrm{CDCl}_{3}$ ) (Figure $\mathrm{S} 15$, Supplementary Material): $\delta$ $6.25(d, J=2.1 \mathrm{~Hz}, 1 \mathrm{H}, \mathrm{H}-6), 6.15(d, J=2.1 \mathrm{~Hz}, 1 \mathrm{H}, \mathrm{H}-2), 2.52\left(\mathrm{t}, J=6.8 \mathrm{~Hz}, 2 \mathrm{H}, \mathrm{H}-1^{\prime}\right)$, $2.15\left(\mathrm{~s}, 3 \mathrm{H}, \mathrm{CH}_{3}-\mathrm{C} 5\right), 1.80\left(\mathrm{~m}, 2 \mathrm{H}, \mathrm{H}-2^{\prime}\right), 1.59\left(\mathrm{~m}, 2 \mathrm{H}, \mathrm{H}-4^{\prime}\right), 1.52\left(\mathrm{~m}, 4 \mathrm{H}, \mathrm{H}-5^{\prime}, \mathrm{H}-6^{\prime}\right), 1.26$ $\left(\mathrm{s}, 3 \mathrm{H}, \mathrm{CH}_{3}-\mathrm{C} 3^{\prime}\right), 1.22\left(\mathrm{~s}, 6 \mathrm{H}, \mathrm{H}-8^{\prime}, \mathrm{CH}_{3}-\mathrm{C}^{\prime}\right) .{ }^{13} \mathrm{C} \mathrm{NMR}\left(100 \mathrm{MHz},\left(\mathrm{CDCl}_{3}\right)\right.$ (Figure S15, Supplementary Material): $\delta 154.6$ (C-3), 154.4 (C-1), 138.2 (C-5), 112.2 (C-4), 108.8 (C-6), 101.5 (C-2), $77.7\left(\mathrm{C}-3^{\prime}\right), 71.2\left(\mathrm{C}-7^{\prime}\right), 44.1\left(\mathrm{C}-6^{\prime}\right), 39.9\left(\mathrm{C}-4^{\prime}\right), 31.1\left(\mathrm{C}-2^{\prime}\right), 29.3\left(\mathrm{CH}_{3}-\mathrm{C}^{\prime}\right), 29.2$ (C-8 $), 23.9\left(\mathrm{CH}_{3}-\mathrm{C}^{\prime}\right), 19.4\left(\mathrm{C}-1^{\prime}\right), 19.3\left(\mathrm{CH}_{3}-\mathrm{C} 5\right), 18.3\left(\mathrm{C}-5^{\prime}\right)$. EIMS $\mathrm{m} / z 278\left[\mathrm{M}^{+}-\mathrm{H}_{2} \mathrm{O}\right](10)$, 137 (100), 175 (17), 177 (9), 260 (10), 278 (10); HR-EIMS [ $\mathrm{M}^{+}-\mathrm{H}_{2} \mathrm{O}$ ] found 278.1877, calcd for $\mathrm{C}_{17} \mathrm{H}_{26} \mathrm{O}_{3} 278.1882$ (Figure S32, Supplementary Material). Fraction III: Compound 26 (26 mg, $12 \%$ yield) obtained as a brown viscous oil. ${ }^{1} \mathrm{H} \mathrm{NMR}\left(400 \mathrm{MHz}, \mathrm{CDCl}_{3}\right.$ ) (Figure S5, Supplementary Material): $\delta 6.26(d, J=2.3 \mathrm{~Hz}, 1 \mathrm{H}, \mathrm{H}-6), 6.21(d, J=2.3 \mathrm{~Hz}, 1 \mathrm{H}, \mathrm{H}-2), 5.13(\mathrm{t}$, $\left.J=6.8 \mathrm{~Hz}, 1 \mathrm{H}, \mathrm{H}-2^{\prime}\right), 3.28\left(d, J=6.8 \mathrm{~Hz}, 2 \mathrm{H}, \mathrm{H}-1^{\prime}\right), 2.22\left(\mathrm{~s}, 3 \mathrm{H}, \mathrm{CH}_{3}-\mathrm{C} 5\right), 2.00\left(\mathrm{~m}, 2 \mathrm{H}, \mathrm{H}-4^{\prime}\right)$, $1.77\left(\mathrm{~s}, 3 \mathrm{H}, \mathrm{CH}_{3}-\mathrm{C}^{\prime}\right), 1.45$ (m, 4H, H-5 y H-6'), 1.21 (s, 6H, H-8 $8^{\prime}$ y $\left.\mathrm{CH}_{3}-\mathrm{C}^{\prime}\right) .{ }^{13} \mathrm{C}$ NMR $\left(100 \mathrm{MHz},\left(\mathrm{CDCl}_{3}\right)\right.$ (Figure S5, Supplementary Material): $\delta 155.3$ (C-3), 154.3 (C-1), 138.5 (C-5), $137.0\left(\mathrm{C}-3^{\prime}\right), 122.4\left(\mathrm{C}-2^{\prime}\right), 117.9$ (C-4), 109.6 (C-6), 100.9 (C-2), $71.3\left(\mathrm{C}-7^{\prime}\right), 43.3\left(\mathrm{C}-6^{\prime}\right)$, $39.9\left(\mathrm{C}-4^{\prime}\right), 29.2\left(\mathrm{C}-8^{\prime}\right.$ y $\left.\mathrm{CH}_{3}-\mathrm{C} 7^{\prime}\right), 25.0\left(\mathrm{C}-1^{\prime}\right), 22.4\left(\mathrm{C}-5^{\prime}\right), 20.1\left(\mathrm{CH}_{3}-\mathrm{C} 5\right), 16.1\left(\mathrm{CH}_{3}-\mathrm{C} 3^{\prime}\right)$. EIMS $m / z 260$ [M $\mathrm{M}^{+}$(20), 123 (15), 137 (100), 175 (31), 177 (14); HR-EIMS [ $\mathrm{M}^{+}-\mathrm{H}_{2} \mathrm{O}$ ] found 260.1780, calcd for $\mathrm{C}_{17} \mathrm{H}_{24} \mathrm{O}_{2} 260.1776$ (Figure S22, Supplementary Material).

4-((E)-3,7-dimethylocta-2,6-dien-1-yl)-6-((e)-7-hydroxy-3,7-dimethyloct-2-en-1yl)benzene-1,3-diol (32) and (E)-4-(3,7-dimethylocta-2,6-dien-1-yl)-6-(3-hydroxy-3,7-dimethyloct-6-en-1-yl)benzene1,3-diol (33)

Compounds 32 and 33 were obtained from 4,6-digeranylresorcinol $(1 \mathrm{~g}, 2.6 \mathrm{mmol})$ and PTSA-PB $(2 \mathrm{~g} \approx 5.5 \mathrm{mmol})$ in dioxane $(50 \mathrm{~mL})$ with $\mathrm{H}_{2} \mathrm{O}(8 \mathrm{~mL})$, following the standard procedure described above for the hydration reaction. Two fractions were obtained by C.C. Fraction I: Compound 33 (32 mg, $3 \%$ yield) obtained as a brown viscous oil. ${ }^{1} \mathrm{H}$ NMR $\left(400 \mathrm{MHz}, \mathrm{CDCl}_{3}\right)$ (Figure S12, Supplementary Material): $\delta 6.74(\mathrm{~s}, 1 \mathrm{H}, \mathrm{H}-5), 6.28(\mathrm{~s}, 1 \mathrm{H}$, $\mathrm{H}-2), 5.30\left(\mathrm{t}, J=7.2 \mathrm{~Hz}, 1 \mathrm{H}, \mathrm{H}-2^{\prime \prime}\right), 5.09\left(\mathrm{~m}, 2 \mathrm{H}, \mathrm{H}-6^{\prime}, \mathrm{H}-6^{\prime \prime}\right), 4.94(\mathrm{~s}, 1 \mathrm{H}, \mathrm{OH}), 3.26(d$, $\left.J=7.2 \mathrm{~Hz}, 2 \mathrm{H}, \mathrm{H}-1^{\prime \prime}\right), 2.65\left(\mathrm{t}, J=6.8 \mathrm{~Hz}, 2 \mathrm{H}, \mathrm{H}-1^{\prime}\right), 2.07$ (m, 8H, H-4', H-5', H-4", H-5"), 1.76 (s, 3H, $\left.\mathrm{CH}_{3}-\mathrm{C}-3^{\prime \prime}\right), 1.68$ (s, 3H, H-8"), 1.67 (s, 3H, $\left.\mathrm{CH}_{3}-\mathrm{C}-7^{\prime \prime}\right), 1.60$ (s, 6H, H-8', $\left.\mathrm{CH}_{3}-\mathrm{C}-7^{\prime}\right)$, $1.27\left(\mathrm{~s}, 3 \mathrm{H}, \mathrm{CH}_{3}-\mathrm{C}-3^{\prime}\right) .{ }^{13} \mathrm{C} \mathrm{NMR}\left(100 \mathrm{MHz},\left(\mathrm{CDCl}_{3}\right)\right.$ (Figure S12, Supplementary Material):

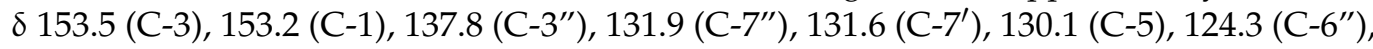
$123.9\left(\mathrm{C}-6^{\prime}\right), 122.5\left(\mathrm{C}-2^{\prime}\right), 118.4(\mathrm{C}-6), 113.1$ (C-4), $104.3(\mathrm{C}-2), 75.9\left(\mathrm{C}-3^{\prime}\right), 39.7\left(\mathrm{C}-4^{\prime}\right), 39.5$ (C-4"), $31.2\left(\mathrm{C}-2^{\prime \prime}\right), 29.1\left(\mathrm{C}-1^{\prime}\right), 26.4\left(\mathrm{C}-5^{\prime}\right), 25.7\left(\mathrm{C}-8^{\prime \prime}\right), 24.2\left(\mathrm{C}-1^{\prime \prime}\right), 22.3\left(\mathrm{CH}_{3}-\mathrm{C}-3^{\prime \prime}\right), 21.4$ (C-5"), $17.7\left(\mathrm{CH}_{3}-\mathrm{C}-7^{\prime \prime}\right), 17.6\left(\mathrm{CH}_{3}-\mathrm{C}-7^{\prime}\right), 16.1\left(\mathrm{CH}_{3}-\mathrm{C}-3^{\prime}\right)$. EIMS m/z $382\left[\mathrm{M}^{+}-\mathrm{H}_{2} \mathrm{O}\right](71), 123$ (15), 137 (47), 189 (33), 191 (46), 259 (100), 297 (67); HR-EIMS [ $\left.\mathrm{M}^{+}-\mathrm{H}_{2} \mathrm{O}\right]$ found 382.2905, calcd for $\mathrm{C}_{26} \mathrm{H}_{38} \mathrm{O}_{2} 382.2872$ (Figure S29, Supplementary Material). Fraction II: Compound 32 (32 mg, 3\% yield) obtained as a brown viscous oil. ${ }^{1} \mathrm{H}-\mathrm{NMR}\left(400 \mathrm{MHz}, \mathrm{CDCl}_{3}\right)$ (Figure S11, Supplementary Material): $\delta=6.78(\mathrm{~s}, 1 \mathrm{H}, \mathrm{H}-5), 6.33(\mathrm{~s}, 1 \mathrm{H}, \mathrm{H}-2), 5.30\left(\mathrm{~m}, 2 \mathrm{H}, \mathrm{H}-2^{\prime}\right.$ and $\left.\mathrm{H}-2^{\prime \prime}\right), 5.07\left(\mathrm{~m}, 2 \mathrm{H}, \mathrm{H}-6^{\prime}\right.$ and $\left.\mathrm{H}-6^{\prime \prime}\right), 3.27\left(d, J=7.2 \mathrm{~Hz}, 4 \mathrm{H}, \mathrm{H}-1^{\prime}\right.$ and $\left.\mathrm{H}-1^{\prime \prime}\right), 2.06(\mathrm{~m}$, $6 \mathrm{H}, \mathrm{H}-4^{\prime},{\mathrm{H}-5^{\prime}}^{\prime}$ and $\left.\mathrm{H}-4^{\prime \prime}\right), 1.76\left(\mathrm{~s}, 6 \mathrm{H}, \mathrm{CH}_{3}-\mathrm{C}-3^{\prime}\right.$ and $\left.\mathrm{CH}_{3}-\mathrm{C}-3^{\prime \prime}\right), 1.68\left(\mathrm{~s}, 3 \mathrm{H}, \mathrm{H}-8^{\prime}\right), 1.60$ (s, $\left.3 \mathrm{H}, \mathrm{CH}_{3}-\mathrm{C}-7^{\prime}\right), 1.21\left(\mathrm{~s}, 6 \mathrm{H}, \mathrm{H}-8^{\prime \prime}\right.$ and $\left.\mathrm{CH}_{3}-\mathrm{C}-7^{\prime \prime}\right) .{ }^{13} \mathrm{C} \mathrm{NMR}\left(100 \mathrm{MHz},\left(\mathrm{CDCl}_{3}\right)\right.$ (Figure S11, Supplementary Material): $\delta 155.7$ (C-1 and C-3), 136.9 (C-3"), $134.8\left(\mathrm{C}-3^{\prime}\right), 130.5\left(\mathrm{C}-7^{\prime}\right), 126.6$ (C-5), $124.1\left(\mathrm{C}-6^{\prime}\right), 123.7$ (C-2"), 122.6 (C-2'), 117.8 (C-6 and C-4), 105.6 (C-2), 70.5 (C-7"), 43.5 (C-6"), 40.2 (C-4"), 39.7 (C-4'), 29.3 (C-8" and $\left.\mathrm{CH}_{3}-\mathrm{C}-7^{\prime \prime}\right), 27.3$ (C-1' and C-1"), 26.1 $\left(\mathrm{C}-5^{\prime}\right), 25.4\left(\mathrm{C}-8^{\prime}\right), 22.6\left(\mathrm{C}-5^{\prime \prime}\right), 17.4\left(\mathrm{CH}_{3}-\mathrm{C}-7^{\prime}\right), 16.3\left(\mathrm{CH}_{3}-\mathrm{C}-3^{\prime \prime}\right), 15.7\left(\mathrm{CH}_{3}-\mathrm{C}-3^{\prime}\right) . \mathrm{EIMS} \mathrm{m} / \mathrm{z}$ $400\left[\mathrm{M}^{+}\right]$(4), 137 (20), 148 (100), 177 (29), 189 (17), 191 (21), 259 (37), 297 (62), 382 (15); HREIMS $\left[\mathrm{M}^{+}-\mathrm{H}_{2} \mathrm{O}\right.$ ] found 382.2869 , calcd for $\mathrm{C}_{26} \mathrm{H}_{38} \mathrm{O}_{2} 382.2872$ (Figure S28, Supplementary Material).

(E)-4-(7-hydroxy-3,7-dimethyloct-2-en-1-yl)-2,3-dimethoxyphenol (28)

Compound 28 was obtained by hydration of 4-geranyl-2,3-dimethoxyphenol (250 mg, $0.9 \mathrm{mmol})$ in dioxane $(30 \mathrm{~mL})$ with $\mathrm{H}_{2} \mathrm{O}(5 \mathrm{~mL})$ in presence of PTSA-PB $(500 \mathrm{mg} \approx 1.5 \mathrm{mmol})$. 
Compound 28 was obtained as a brown viscous oil (32 mg, $12 \%$ yield). ${ }^{1} \mathrm{H}$ NMR (400 MHz, $\left.\mathrm{CDCl}_{3}\right)$ (Figure S7, Supplementary Material): $\delta 6.76(d, J=8.3 \mathrm{~Hz}, 1 \mathrm{H}, \mathrm{H}-5), 6.64(d$, $J=8.3 \mathrm{~Hz}, 1 \mathrm{H}, \mathrm{H}-6), 5.72(\mathrm{~s}, 1 \mathrm{H}, \mathrm{OH}), 5.25\left(\mathrm{t}, J=7.2 \mathrm{~Hz}, 1 \mathrm{H}, \mathrm{H}-2^{\prime}\right), 3.91\left(\mathrm{~s}, 3 \mathrm{H}, \mathrm{CH}_{3} \mathrm{O}-\mathrm{C} 2\right)$, $3.83\left(\mathrm{~s}, 3 \mathrm{H}, \mathrm{CH}_{3} \mathrm{O}-\mathrm{C} 3\right), 3.26\left(d, J=7.3 \mathrm{~Hz}, 2 \mathrm{H}, \mathrm{H}-1^{\prime}\right), 2.02\left(\mathrm{t}, J=6.8 \mathrm{~Hz}, 2 \mathrm{H}, \mathrm{H}-6^{\prime}\right), 1.70(\mathrm{~s}$, $\left.3 \mathrm{H}, \mathrm{CH}_{3}-\mathrm{C}^{\prime}\right), 1.46\left(\mathrm{~m}, 4 \mathrm{H}, \mathrm{H}-4^{\prime}, \mathrm{H}-5^{\prime}\right), 1.20\left(\mathrm{~s}, 6 \mathrm{H}, \mathrm{H}-8^{\prime}\right.$ y $\left.\mathrm{CH}_{3}-\mathrm{C}^{\prime}\right) .{ }^{13} \mathrm{C} \mathrm{NMR}(100 \mathrm{MHz}$, $\left(\mathrm{CDCl}_{3}\right)$ (Figure S7, Supplementary Material): $\delta 150.7$ (C-2), 147.8 (C-1), 139.9 (C-3), 135.6 (C-3'), 126.9 (C-4), 124.2 (C-5), $123.3\left(\mathrm{C}-2^{\prime}\right), 110.2(\mathrm{C}-6), 71.1\left(\mathrm{C}-7^{\prime}\right), 60.7\left(\mathrm{CH}_{3} \mathrm{O}-\mathrm{C} 2\right), 60.4$ $\left(\mathrm{CH}_{3} \mathrm{O}-\mathrm{C} 3\right), 43.5\left(\mathrm{C}-6^{\prime}\right), 40.1\left(\mathrm{C}-4^{\prime}\right), 29.3\left(\mathrm{C}-8^{\prime}\right.$ y $\left.\mathrm{CH}_{3}-\mathrm{C}^{\prime}\right), 27.8\left(\mathrm{C}-1^{\prime}\right), 22.6\left(\mathrm{C}-5^{\prime}\right), 16.1\left(\mathrm{CH}_{3}-\right.$

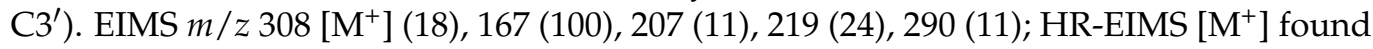
308.1993, calcd for $\mathrm{C}_{18} \mathrm{H}_{28} \mathrm{O}_{4} 308.1988$ (Figure S24, Supplementary Material).

(E)-2-(7-hydroxy-3,7-dimethyloct-2-en-1-yl)-4,5-dimethoxyphenol (29) and 8-(2-hydroxy-4,5-dimethoxyphenyl)-2,6-dimethyloctane-2,6-diol (37)

Compounds 29 and 37 were obtained by the hydration reaction described above, from 6-geranyl-4,5-dimethoxyphenol $(300 \mathrm{mg}, 1.0 \mathrm{mmol})$ in polyethylene glycol $400(7 \mathrm{~mL})$ with $\mathrm{H}_{2} \mathrm{O}(6 \mathrm{~mL})$ and PTSA-PB $(300 \mathrm{mg} \approx 1.0 \mathrm{mmol})$. Two fractions were obtained by C.C. Fraction I: Compound 29 (48 mg, 15\% yield) obtained as a brown viscous oil. ${ }^{1} \mathrm{H}$ NMR (400 MHz, $\mathrm{CDCl}_{3}$ ) (Figure S8, Supplementary Material): $\delta 6.62(\mathrm{~s}, 1 \mathrm{H}, \mathrm{H}-3), 6.45(\mathrm{~s}, 1 \mathrm{H}$, $\mathrm{H}-6), 5.31\left(\mathrm{~m}, 1 \mathrm{H}, \mathrm{H}-2^{\prime}\right), 3.82$ (s, 6H, $\mathrm{CH}_{3} \mathrm{O}-\mathrm{C} 4$ y CH$\left._{3} \mathrm{O}-\mathrm{C} 5\right), 3.29$ (d, 2H, $\left.\mathrm{H}_{-1}^{\prime}\right), 2.06$ (m, $\left.2 \mathrm{H}, \mathrm{H}-4^{\prime}\right), 1.77\left(\mathrm{~s}, 3 \mathrm{H}, \mathrm{CH}_{3}-\mathrm{C}^{\prime}\right) 1.50\left(\mathrm{~m}, 4 \mathrm{H}, \mathrm{H}-5^{\prime}\right.$ y H-6 $\left.{ }^{\prime}\right) ; 1.21\left(\mathrm{~s}, 6 \mathrm{H}, \mathrm{CH}_{3}-\mathrm{C}^{\prime}\right.$ y $\left.\mathrm{H}-8^{\prime}\right)$. ${ }^{13} \mathrm{C}$ NMR $\left(100 \mathrm{MHz},\left(\mathrm{CDCl}_{3}\right)\right.$ (Figure S8, Supplementary Material): $\delta 148.3(\mathrm{C}-1), 148.3$ (C-5), 142.9 (C-4), $138.3\left(\mathrm{C}-3^{\prime}\right), 122.1\left(\mathrm{C}-2^{\prime}\right), 117.3(\mathrm{C}-2), 113.7(\mathrm{C}-3), 101.2(\mathrm{C}-6), 70.1\left(\mathrm{C}-7^{\prime}\right)$, $56.7\left(\mathrm{CH}_{3} \mathrm{O}-\mathrm{C} 5\right), 56.0\left(\mathrm{CH}_{3} \mathrm{O}-\mathrm{C} 4\right), 43.3\left(\mathrm{C}-6^{\prime}\right), 40.0\left(\mathrm{C}-4^{\prime}\right), 29.5\left(\mathrm{C}-1^{\prime}\right), 29.3\left(\mathrm{C}-8^{\prime}\right.$ y $\left.\mathrm{CH}_{3}-\mathrm{C}^{\prime}\right)$, $22.5\left(\mathrm{C}^{\prime}\right), 16.2\left(\mathrm{CH}_{3}-\mathrm{C}^{\prime}\right)$. EIMS $m / z 308$ [M $\left.{ }^{+}\right]$(8), 167 (100), 205 (57), 290 (19); HR-EIMS $\left[\mathrm{M}^{+}\right]$found 308.1982, calcd for $\mathrm{C}_{18} \mathrm{H}_{28} \mathrm{O}_{4} 308.1988$ (Figure S25, Supplementary Material). Fraction II: Compound 37 (54 mg, 16\% yield) obtained as a brown viscous oil. ${ }^{1} \mathrm{H}$ NMR $\left(400 \mathrm{MHz}, \mathrm{CDCl}_{3}\right.$ ) (Figure S16, Supplementary Material): $\delta 6.54\left(\mathrm{~s}, 1 \mathrm{H}, \mathrm{H}-6^{\prime}\right), 6.36(\mathrm{~s}, 1 \mathrm{H}$, $\left.\mathrm{H}-3^{\prime}\right), 3.81\left(\mathrm{~s}, 6 \mathrm{H}, \mathrm{CH}_{3} \mathrm{O}-\mathrm{C}^{\prime}\right.$ y $\left.\mathrm{CH}_{3} \mathrm{O}-\mathrm{C}^{\prime}\right), 2.66(\mathrm{~m}, 2 \mathrm{H}, \mathrm{H}-8), 1.78(\mathrm{~m}, 2 \mathrm{H}, \mathrm{H}-7), 1.58(\mathrm{~m}$, $2 \mathrm{H}, \mathrm{H}-5), 1.47\left(\mathrm{~m}, 4 \mathrm{H}, \mathrm{H}-3\right.$ y H-4), $1.26\left(\mathrm{~s}, 3 \mathrm{H}, \mathrm{CH}_{3}-\mathrm{C} 6\right) ; 1.22\left(\mathrm{~s}, 6 \mathrm{H}, \mathrm{CH}_{3}-\mathrm{C} 2\right.$ y H-1$) .{ }^{13} \mathrm{C}$ NMR $\left(100 \mathrm{MHz},\left(\mathrm{CDCl}_{3}\right)\right.$ (Figure S16, Supplementary Material): $\delta 148.4\left(\mathrm{C}-2^{\prime}\right), 147.6\left(\mathrm{C}-4^{\prime}\right)$, 142.6 (C-5'), $112.3\left(\mathrm{C}-1^{\prime}\right), 111.4\left(\mathrm{C}-6^{\prime}\right), 101.3\left(\mathrm{C}-3^{\prime}\right), 75.8(\mathrm{C}-6), 71.0(\mathrm{C}-2), 56.5\left(\mathrm{CH}_{3} \mathrm{O}-\mathrm{C}^{\prime}\right)$, 55,8 $\left(\mathrm{CH}_{3} \mathrm{O}-\mathrm{C} 4^{\prime}\right), 44.2$ (C-3), $40.2(\mathrm{C}-5), 31.1$ (C-7), $29.4(\mathrm{C}-1), 29.3\left(\mathrm{CH}_{3}-\mathrm{C} 2\right), 23.9$ (C-8), 21.7 $\left(\mathrm{CH}_{3}\right.$-C6), 18.4 (C4). EIMS m/z $308\left(\mathrm{M}^{+}-\mathrm{H}_{2} \mathrm{O}, 21\right), 167$ (100), 205 (8), 290 (8); HR-EIMS [M ${ }^{+}$ $-\mathrm{H}_{2} \mathrm{O}$ ] found 308.1982, calcd for $\mathrm{C}_{18} \mathrm{H}_{28} \mathrm{O}_{4} 308.1988$ (Figure S33, Supplementary Material).

(E)-2-(7-hydroxy-3,7-dimethyloct-2-en-1-yl)-3,5-dimethoxybenzene-1,4-diol (30)

Compound 30 was obtained by the hydration reaction described above, from 2geranyl-3,5-dimethoxhydroquinone $(200 \mathrm{mg}, 0.7 \mathrm{mmol})$ in dioxane $(30 \mathrm{~mL})$ and $\mathrm{H}_{2} \mathrm{O}$ $(5 \mathrm{~mL})$ and PTSA-PB $(300 \mathrm{mg} \approx 1.0 \mathrm{mmol})$. Compound 30 was obtained as a brown viscous oil (66 mg, 31\% yield). ${ }^{1} \mathrm{H}$ NMR (400 MHz, $\mathrm{CDCl}_{3}$ ) (Figure S9, Supplementary Material): $\delta$ $5.92(\mathrm{~s}, 1 \mathrm{H}, \mathrm{H}-6) ; 5.04\left(\mathrm{~m}, 1 \mathrm{H}, \mathrm{H}-2^{\prime}\right), 3.97\left(\mathrm{~s}, 3 \mathrm{H}, \mathrm{CH}_{3} \mathrm{O}-\mathrm{C} 3\right) ; 3.78\left(\mathrm{~s}, 3 \mathrm{H}, \mathrm{CH}_{3} \mathrm{O}-\mathrm{C} 5\right) ; 3.15$ (d, $\left.J=7.2 \mathrm{~Hz}, 2 \mathrm{H}, \mathrm{H}-\mathrm{1}^{\prime}\right) ; 1.94\left(\mathrm{~m}, 2 \mathrm{H}, \mathrm{H}-4^{\prime}\right) ; 1.72\left(\mathrm{~s}, 3 \mathrm{H}, \mathrm{CH}_{3}-\mathrm{C}^{\prime}\right) 1.50\left(\mathrm{~m}, 4 \mathrm{H}, \mathrm{H}-5^{\prime}\right.$ y H-6 $\left.{ }^{\prime}\right)$; $1.20\left(\mathrm{~s}, 6 \mathrm{H}, \mathrm{CH}_{3}-\mathrm{C}^{\prime}\right.$ y H-8 $\left.{ }^{\prime}\right) .{ }^{13} \mathrm{C}$ NMR $\left(100 \mathrm{MHz},\left(\mathrm{CDCl}_{3}\right)\right.$ (Figure S9, Supplementary Material): $\delta 157.3$ (C-1); 154.1 (C-3); 150.7 (C-5); 137.2 (C-3'); 132.7 (C-4); 120.0 (C-2'); 114.2 (C-2); 106.9 (C-6); 70.9 (C-7'); $60.9\left(\mathrm{CH}_{3} \mathrm{O}-\mathrm{C} 3\right) ; 56.3\left(\mathrm{CH}_{3} \mathrm{O}-\mathrm{C} 5\right) ; 43.4\left(\mathrm{C}-6^{\prime}\right) ; 40.0\left(\mathrm{C}-4^{\prime}\right) ; 29.2$ $\left(\mathrm{C}-8^{\prime}\right.$ y $\left.\mathrm{CH}_{3}-\mathrm{C}^{\prime}\right) ; 22.5\left(\mathrm{C}-1^{\prime}\right.$ and $\left.\mathrm{C}-5^{\prime}\right) ; 16.0\left(\mathrm{CH}_{3}-\mathrm{C}^{\prime}\right)$. EIMS $\mathrm{m} / z 324\left[\mathrm{M}^{+}\right]$(4), 109 (11), 123 (13), 139 (14), 153 (12), 170 (12), 183 (93), 194 (23), 207 (20), 221 (100), 233, (40), 248 (23), 261 (18), 304 (19), 307 (13), 322 (19); HR-EIMS [ $\mathrm{M}^{+}$] found 324.1936, calcd for $\mathrm{C}_{18} \mathrm{H}_{28} \mathrm{O}_{5}$ 324.1937 (Figure S26, Supplementary Material).

\section{8-(2-hydroxy-3,4,5-trimethoxyphenyl)-2,6-dimethyloctane-2,6-diol (38)}

Compound 38 was obtained by the hydration reaction described above, from 6geranyl-2,3,4-trimethoxphenol (100 $\mathrm{mg}, 0.3 \mathrm{mmol}$ ) and PTSA-PB (200 $\mathrm{mg} \approx 0.6 \mathrm{mmol})$ in dioxane $(20 \mathrm{~mL})$ with $\mathrm{H}_{2} \mathrm{O}(4 \mathrm{~mL})$. Compound 38 was obtained as a brown viscous oil (40 mg, 36\% yield). ${ }^{1} \mathrm{H}$ NMR (400 MHz, $\mathrm{CDCl}_{3}$ ) (Figure S17, Supplementary Material): $\delta$ 
6.34 (s, 1H, H-6 $\left.{ }^{\prime}\right), 3.85$ (s, 3H, $\left.\mathrm{CH}_{3} \mathrm{O}-\mathrm{C}^{\prime}\right), 3.85$ (s, 3H, $\left.\mathrm{CH}_{3} \mathrm{O}-\mathrm{C}^{\prime}\right), 3.78\left(\mathrm{~s}, 3 \mathrm{H}, \mathrm{CH}_{3} \mathrm{O}-\mathrm{C}^{\prime}\right)$, 2.70 (m, 2H, H-8), 1.78 (m, 2H, H-7), 1.63 (m, 2H, H-4), 1.48 (m, 4H, H-3 y H-5), 1.29 (s, $\left.3 \mathrm{H}, \mathrm{CH}_{3}-\mathrm{C} 6\right), 1.21$ (s, 6H, H-1, $\left.\mathrm{CH}_{3}-\mathrm{C} 2 \mathrm{y} \mathrm{H}-1\right) .{ }^{13} \mathrm{C} \mathrm{NMR}\left(100 \mathrm{MHz},\left(\mathrm{CDCl}_{3}\right)\right.$ (Figure S17, Supplementary Material): $\delta 146.1\left(\mathrm{C}-5^{\prime}\right), 142.6\left(\mathrm{C}-4^{\prime}\right), 141.7\left(\mathrm{C}-2^{\prime}\right), 141.5\left(\mathrm{C}-3^{\prime}\right), 116.1\left(\mathrm{C}-1^{\prime}\right)$, $107.2\left(\mathrm{C}-6^{\prime}\right), 75.9(\mathrm{C}-6), 71.0(\mathrm{C}-2), 61.3\left(\mathrm{CH}_{3} \mathrm{O}-\mathrm{C}^{\prime}\right), 60.9\left(\mathrm{CH}_{3} \mathrm{O}-\mathrm{C}^{\prime}\right), 56.4\left(\mathrm{CH}_{3} \mathrm{O}-\mathrm{C}^{\prime}\right), 44.2$ (C-3), 40.4 (C-5), 31.1 (C-7), $29.4\left(\mathrm{CH}_{3}-\mathrm{C} 2\right), 29.2$ (C-1), $23.7\left(\mathrm{CH}_{3}-\mathrm{C} 6\right), 22.3$ (C-8), 19.5 (C-4). EIMS $m / z 338$ [M+ $\left.-\mathrm{H}_{2} \mathrm{O}\right]$ (17), 197 (100), 320 (9); HR-EIMS [ $\mathrm{M}^{+}-\mathrm{H}_{2} \mathrm{O}$ ] found 338.2107, calcd for $\mathrm{C}_{19} \mathrm{H}_{30} \mathrm{O}_{5} 338.2093$ (Figure S34, Supplementary Material).

2-(3-hydroxy-3,7-dimethyloct-6-en-1-yl)benzene-1,4-diol (25) and

2-(3,7-dihydroxy-3,7-dimethyloctyl)benzene-1,4-diol (35)

Compound 35 was obtained by the hydration reaction described above, from 2geranylhydroquinone (300 mg, $1.2 \mathrm{mmol})$ in polyethylene glycol $400(7 \mathrm{~mL})$ and $\mathrm{H}_{2} \mathrm{O}$ $(6 \mathrm{~mL})$ and PTSA-PB $(300 \mathrm{mg} \approx 1.0 \mathrm{mmol})$. Two fractions were obtained by C.C. Fraction I: Compound 25 was obtained as a brown viscous oil (39 mg, 12\% yield). The spectroscopic data for $\mathbf{2 5}$ were consistent with those previously reported [31,32] Fraction II: Compound 35 was obtained as a brown viscous oil (35 mg, 10\% yield). ${ }^{1} \mathrm{H} \mathrm{NMR}\left(400 \mathrm{MHz}, \mathrm{CDCl}_{3}\right)$ (Figure S14, Supplementary Material): $\delta 6.65(d, J=8.6 \mathrm{~Hz}, 1 \mathrm{H}, \mathrm{H}-6), 6.56(\mathrm{~m}, 2 \mathrm{H}, \mathrm{H}-3$ y H-5), 2.70 (m, 2H, H-1') 1.76 (m, 2H, H-2'), 1.58 (m, 2H, H-4'), 1.47 (m, 4H, H-5' y H-6 ${ }^{\prime}$, 1.25 (s, 3H, $\left.\mathrm{CH}_{3}-\mathrm{C}^{\prime}\right) ; 1.22$ (s, 6H, $\mathrm{CH}_{3}-\mathrm{C}^{\prime}$ y H-8 $) .{ }^{13} \mathrm{C} \mathrm{NMR}\left(100 \mathrm{MHz},\left(\mathrm{CDCl}_{3}\right)\right.$ (Figure S14, Supplementary Material): $\delta 148.6$ (C-4), 147.7 (C-1), 121.9 (C-2), 117.8 (C-3), 115.4 (C-6), $114.5(\mathrm{C}-5), 75.8\left(\mathrm{C}-3^{\prime}\right), 71.3\left({\left.\mathrm{C}-7^{\prime}\right)}^{\prime}, 44.2\left(\mathrm{C}-6^{\prime}\right), 40.1\left(\mathrm{C}-4^{\prime}\right), 31.0\left(\mathrm{C}-2^{\prime}\right), 29.4\left(\mathrm{C}-8^{\prime}\right)\right.$, $29.2\left(\mathrm{CH}_{3}-\mathrm{C}^{\prime}\right), 24.0\left(\mathrm{C}-1^{\prime}\right), 22.3\left(\mathrm{CH}_{3}-\mathrm{C}^{\prime}\right), 18.4\left(\mathrm{C}^{\prime}\right)$. EIMS m/z $264\left[\mathrm{M}^{+}-\mathrm{H}_{2} \mathrm{O}\right](34), 123$ (100), 161 (25), 163 (30), 175 (19), 246 (19); HR-EIMS [ $\left.{ }^{+}-\mathrm{H}_{2} \mathrm{O}\right]$ found 264.1720, calcd for $\mathrm{C}_{16} \mathrm{H}_{24} \mathrm{O}_{3} 264.1725$ (Figure S31, Supplementary Material).

\subsection{Antifungal Assays}

Antifungal activity of all synthesized compounds was evaluated by determining mycelial growth inhibition of $B$. cinerea in the radial growth test. Assayed compounds in ethanol solution were added to potato dextrose agar (PDA) at $50{ }^{\circ} \mathrm{C}$, reaching final concentrations in the range 10 to $250 \mathrm{ppm}$. The medium with dissolved geranylated phenols was poured into $50 \mathrm{~mm}$ diameter Petri dishes. After solidification, Petri dishes were inoculated with $4 \mathrm{~mm}$ diameter agar discs with thin mycelium of $B$. cinerea. Negative control containing only PDA culture medium, and positive control with BC-1000 at the same concentrations of tested compounds were prepared. Three replicates were made for each treatment. All dishes were incubated at $23{ }^{\circ} \mathrm{C}$ under $16 \mathrm{~h}$ light $/ 8 \mathrm{~h}$ dark photoperiod. After 3 days, the mycelial growth diameter was measured and the percentage of mycelial inhibition (\%I) was calculated. These values were plotted against fungicide concentration and fitted to a dose-response equation. This fitting gives $\mathrm{EC}_{50}$, the concentration at which mycelial growth is inhibited to $50 \%$ as compared to the negative control. Plotting of the data, fitting and $\mathrm{EC}_{50}$ calculation were carried out with Origin 8.0. Significant differences were evaluated with a two-way analysis of variance (Tukey's test; $p<0.05$ ).

\subsection{Molecular Docking}

The X-ray coordinates of SDH enzyme in complex with carboxin were obtained from the RCSB PDB database (PDB code 2FBW). PDB structures for docking were prepared using the Protein Preparation Wizard (Schrodinger, LLC, New York, NY, USA, 2018) that is accessible within the Maestro program (Maestro, version 11.8; Schrodinger, LLC: New York, NY, USA, 2018). Three-dimensional structures of ligands to be docked were generated and prepared using LigPrep as implemented in Maestro 11.5 (LigPrep, Schrodinger, LLC: New York, NY, USA, 2018). Docking of ligands was carried out using Glide program (Schrödinger, LLC, New York, NY, USA, 2021). Details used for sampling of group orientations, optimization of receptor, minimization on the ligand-protein complexes, docking of compounds and ligand poses have been given elsewhere [33,34]. Briefly, GlideScore-a modified version of ChemScore-was used to estimate binding affinity and rank ligands. 
Ligands were docked using the extra precision mode (Glide XP), whereas XP Pose Rank was used to select the best-docked pose for each ligand.

\section{Conclusions}

Geranylated phenols with different functional groups in the aromatic ring were synthesized by direct coupling of phenol and geraniol under microwave irradiation. Yields of $21-32 \%$ were obtained in reduced reaction time $(10 \mathrm{~min})$. Hydration of geranylated phenols, using $p$-toluenesulfonic acid bound to a polymer matrix as catalyst, leads to compounds with one or two hydroxyl groups in the side alkyl chain with yields ranging from 10 to $36 \%$.

The mycelium growth inhibition of B. cinerea induced by all synthesized geranylated phenols has been studied and $\mathrm{EC}_{50}$ values have determined for all tested compounds. The data indicate that activity depends on the structure of the phenol ring and hydration degree of the side alkyl chain. The most active compound is compound 30, which has two hydroxyl groups in positions 1 and 4 and a mono hydrated side alkyl chain. A molecular docking study shows that binding energies of these compounds to the allosteric binding site of SDH are in the range of -9.2 to $-5.4 \mathrm{kcal} \mathrm{mol}^{-1}$. The results suggest that hydroxyl groups in positions 1 and 4 and in the side alkyl chain are important in the binding of compounds to the active site, and that the experimental antifungal activity correlates with the number of $\mathrm{H}$-bonds that can be formed in the binding site.

Supplementary Materials: The following are available online: Figure S1: NMR spectra of (E)2-(3,7-dimethylocta-2,6-dien-1-yl)-3,5-dimethoxybenzene-1,4-diol (19); Figure S2: NMR spectra of (E)-2-(3,7-dimethylocta-2,6-dien-1-yl)-3,5-dimethoxycyclohexa-2,5-diene-1,4-dione (20); Figure S3: NMR spectra of (E)-4-(7-hydroxy-3,7-dimethyloct-2-en-1-yl)benzene-1,3-diol (23); Figure S4: NMR spectra of 4-(3-hydroxy-3,7-dimethyloct-6-en-1-yl)benzene-1,3-diol (24); Figure S5: NMR spectra of (E)-4-(7-hydroxy-3,7-dimethyloct-2-en-1-yl)-5-methylbenzene-1,3-diol (26); Figure S6: NMR spectra of 4-(3-hydroxy-3,7-dimethyloct-6-en-1-yl)-5-methylbenzene-1,3-diol (27); Figure S7: NMR spectra of (E)-4-(7-hydroxy-3,7-dimethyloct-2-en-1-yl)-2,3-dimethoxyphenol (28); Figure S8: NMR spectra of (E)-2-(7-hydroxy-3,7-dimethyloct-2-en-1-yl)-4,5-dimethoxyphenol (29); Figure S9: NMR spectra of (E)-2-(7-hydroxy-3,7-dimethyloct-2-en-1-yl)-3,5-dimethoxybenzene-1,4-diol (30); Figure S10: NMR spectra of (E)-2-(7-hydroxy-3,7-dimethyloct-2-en-1-yl)-3,5-dimethoxycyclohexa2,5-diene-1,4-dione (31); Figure S11: NMR spectra of 4-((E)-3,7-dimethylocta-2,6-dien-1-yl)-6-((E)7-hydroxy-3,7-dimethyloct-2-en-1-yl)benzene-1,3-diol (32); Figure S12: NMR spectra of (E)-4-(3,7dimethylocta-2,6-dien-1-yl)-6-(3-hydroxy-3,7-dimethyloct-6-en-1-yl)benzene-1,3-diol (33); Figure S13: NMR spectra of (E)-4-(7-hydroxy-3,7-dimethyloct-2-en-1-yl)benzene-1,3-diol (23) and 4-(3,7dihydroxy-3,7-dimethyloctyl)benzene-1,3-diol (34); Figure S14: NMR spectra of 2-(3,7-dihydroxy-3,7dimethyloctyl)benzene-1,4-diol (35); Figure S15: NMR spectra of 4-(3,7-dihydroxy-3,7-dimethyloctyl)5-methylbenzene-1,3-diol (36); Figure S16: NMR spectra of 8-(2-hydroxy-4,5-dimethoxyphenyl)-2,6dimethyloctane-2,6-diol (37); Figure S17: NMR spectra of 8-(2-hydroxy-3,4,5-trimethoxyphenyl)-2,6dimethyloctane-2,6-diol (38); Figure S18: HRMS (EI+) spectrum of (E)-2-(3,7-dimethylocta-2,6-dien-1yl)-3,5-dimethoxybenzene-1,4-diol (19); Figure S19: HRMS (EI+) spectrum of (E)-2-(3,7-dimethylocta2,6-dien-1-yl)-3,5-dimethoxycyclohexa-2,5-diene-1,4-dione (20); Figure S20: HRMS (EI+) spectrum of (E)-4-(7-hydroxy-3,7-dimethyloct-2-en-1-yl)benzene-1,3-diol (23); Figure S21: HRMS (EI+) spectrum of 4-(3-hydroxy-3,7-dimethyloct-6-en-1-yl)benzene-1,3-diol (24); Figure S22: HRMS (EI+) spectrum of (E)-4-(7-hydroxy-3,7-dimethyloct-2-en-1-yl)-5-methylbenzene-1,3-diol (26); Figure S23: HRMS (EI+) spectrum of 4-(3-hydroxy-3,7-dimethyloct-6-en-1-yl)-5-methylbenzene-1,3-diol (27); Figure S24: HRMS (EI+) spectrum of (E)-4-(7-hydroxy-3,7-dimethyloct-2-en-1-yl)-2,3-dimethoxyphenol (28); Figure S25: HRMS (EI+) spectrum of (E)-2-(7-hydroxy-3,7-dimethyloct-2-en-1-yl)-4,5-dimethoxyphenol (29); Figure S26: HRMS (EI+) spectrum of (E)-2-(7-hydroxy-3,7-dimethyloct-2-en-1-yl)-3,5-dimethoxyb enzene-1,4-diol (30); Figure S27: HRMS (EI+) spectrum of (E)-2-(7-hydroxy-3,7-dimethyloct-2-en-1yl)-3,5-dimethoxycyclohexa-2,5-diene-1,4-dione (31); Figure S28: HRMS (EI+) spectrum of 4-((E)-3,7dimethylocta-2,6-dien-1-yl)-6-((E)-7-hydroxy-3,7-dimethyloct-2-en-1-yl)benzene-1,3-diol (32); Figure S29: HRMS (EI+) spectrum of (E)-4-(3,7-dimethylocta-2,6-dien-1-yl)-6-(3-hydroxy-3,7-dimethyloct-6en-1-yl)benzene-1,3-diol (33); Figure S30: HRMS (EI+) spectrum of 4-(3,7-dihydroxy-3,7-dimethylocty 1)benzene-1,3-diol (34); Figure S31: HRMS (EI+) spectrum of 2-(3,7-dihydroxy-3,7-dimethyloctyl)benz 
ene-1,4-diol (35); Figure S32: HRMS (EI+) spectrum of 4-(3,7-dihydroxy-3,7-dimethyloctyl)-5-methylb enzene-1,3-diol (36); Figure S33: HRMS (EI+) spectrum of 8-(2-hydroxy-4,5-dimethoxyphenyl)-2,6dimethyloctane-2,6-diol (37); Figure S34: HRMS (EI+) spectrum of 8-(2-hydroxy-3,4,5-trimethoxyphen yl)-2,6-dimethyloctane-2,6-diol (38).

Author Contributions: Conceptualization, L.T., M.S., K.D. and A.E.-B.; methodology, M.S., L.E., K.D., J.K., S.R. and Á.A.; validation, L.T., M.S., K.D. and A.E.-B.; formal analysis, L.T., L.E., K.D., M.S., A.F.O. and Á.A.; investigation, J.K., L.T., M.S., K.D. and L.E.; resources, L.T. and K.D.; writing-original draft preparation, M.S., L.T. and K.D.; writing-review and editing, A.F.O. and L.T.; supervision, L.T. and K.D.; project administration, L.T.; funding acquisition, L.T. All authors have read and agreed to the published version of the manuscript.

Funding: This research was funded by Fondo Nacional de Desarrollo Científico y Tecnológico (FONDECYT), Agencia Nacional de Investigación y Desarrollo (ANID), grants No. 11160319 and No. 1201097.

Institutional Review Board Statement: Not applicable.

Informed Consent Statement: Not applicable.

Data Availability Statement: The data presented in this study are available in the Supplementary Material.

Acknowledgments: L.T. acknowledges support from Direccion General de Investigación, Innovacion y Emprendimiento, Universidad Técnica Federico Santa María (DGIIE-USM), whereas M.S. thanks Programa de Iniciación en Investigación Científica (PIIC-DGIIE-USM) and ANID (National Doctoral Fellowship No. 21160147). Fondo de Equipamiento Científico y Tecnológico (FONDEQUIP) grants EQM200241 and EQM190025.

Conflicts of Interest: The authors declare no conflict of interest.

Sample Availability: Samples of the compounds are not available from the authors.

\section{References}

1. De Rosa, S.; De Giulio, A.; Iodice, C. Biological Effects of Prenylated Hydroquinones-Structure-Activity Relationship Studies in Antimicrobial, Brine Shrimp, and Fish Lethality Assays. J. Nat. Prod. 1994, 57, 1711-1716. [CrossRef]

2. Bifulco, G.; Bruno, I.; Minale, L.; Riccio, R.; Debitus, C.; Bourdy, G.; Vassas, A.; Lavayre, J. Bioactive Prenylhydroquinone Sulfates and a Novel C31 Furanoterpene Alcohol Sulfate from the Marine Sponge, Ircinia Sp. J. Nat. Prod. 1995, 58, 1444-1449. [CrossRef]

3. Bowden, B.; Coll, J. Studies of Australian soft corals. XXVI. Tetraprenylbenzoquinone derivatives from a Nephthea species of soft coral (Octocorallia, Alcyonacea). Aust. J. Chem. 1981, 34, 2677-2681. [CrossRef]

4. Ravi, B.; Wells, R. Lipid and terpenoid metabolites of the Gorgonian Plexaura flava. Aust. J. Chem. 1982, 35, 105-112. [CrossRef]

5. Howard, B.M.; Clarkson, K.; Bernstein, R.L. Simple prenylated hydroquinone derivatives from the marine urochordate aplidium californicum. Natural anticancer and antimutagenic agents. Tetrahedron Lett. 1979, 20, 4449-4452. [CrossRef]

6. Targett, N.M.; Keeran, W.S. A Terpenehydroquinone from the Marine Ascidian Aplidium constellatum. J. Nat. Prod. 1984, 47, 556-557. [CrossRef]

7. Guella, G.; Mancini, I.; Pietra, F. Verapliquinones-Novel Diprenylquinones from An Aplidium Sp (Ascidiacea) of Ile-Verte Waters, Brittany. Helv. Chim. Acta 1987, 70, 621-626. [CrossRef]

8. Faulkner, D.J. Marine natural products. Nat. Prod. Res. 2001, 18, 1R-49R.

9. Baeza, E.; Catalan, K.; Pena-Cortes, H.; Espinoza, L.; Villena, J.; Carrasco, H. Synthesis of Geranylhydroquinone Derivatives with Potential Cytotoxic Activity. Quim. Nova 2012, 35, 523-526. [CrossRef]

10. Taborga, L.; Espinoza, L.; Moller, A.; Carrasco, H.; Cuellar, M.; Villena, J. Antiproliferative effect and apoptotic activity of linear geranylphenol derivatives from phloroglucinol and orcinol. Chem. Biol. Interact. 2016, 247, 22-29. [CrossRef]

11. Espinoza, L.; Taborga, L.; Diaz, K.; Olea, A.F.; Peña-Cortes, H. Synthesis of linear geranylphenols and their effect on mycelial growth of plant pathogen Botrytis cinerea. Molecules 2014, 19, 1512-1526. [CrossRef] [PubMed]

12. Chavez, M.I.; Soto, M.; Taborga, L.; Diaz, K.; Olea, A.F.; Bay, C.; Pena-Cortes, H.; Espinoza, L. Synthesis and in vitro antifungal activity against Botrytis cinerea of geranylated phenols and their phenyl acetate derivatives. Int. J. Mol. Sci. 2015, 16, 19130-19152. [CrossRef] [PubMed]

13. Taborga, L.; Diaz, K.; Olea, A.F.; Reyes-Bravo, P.; Flores, M.E.; Pena-Cortes, H.; Espinoza, L. Effect of Polymer Micelles on Antifungal Activity of Geranylorcinol Compounds against Botrytis cinerea. J. Agric. Food Chem. 2015, 63, 6890-6896. [CrossRef] [PubMed]

14. Soto, M.; Espinoza, L.; Chavez, M.I.; Diaz, K.; Olea, A.F.; Taborga, L. Synthesis of New Hydrated Geranylphenols and in Vitro Antifungal Activity against Botrytis cinerea. Int. J. Mol. Sci. 2016, 17, 840. [CrossRef] [PubMed] 
15. Chavez, M.I.; Soto, M.; Cimino, F.A.; Olea, A.F.; Espinoza, L.; Diaz, K.; Taborga, L. In Vitro Antifungal Activity of New and Known Geranylated Phenols against Phytophthora cinnamomi Rands. Int. J. Mol. Sci. 2018, 19, 1601. [CrossRef] [PubMed]

16. Qu, T.; Gao, S.; Li, J.; Hao, J.J.; Ji, P. Synthesis and antifungal activity of 2-allylphenol derivatives against fungal plant pathogens. Pestic. Biochem. Physiol. 2017, 135, 47-51. [CrossRef] [PubMed]

17. Baeza, E.; Catalan, K.; Villena, J.; Carrasco, H.; Cuellar, M.; Espinoza, L. Synthesis and cytotoxic activity of geranylmethoxyhydroquinone derivatives. J. Chil. Chem.Soc. 2012, 57, 1219-1223. [CrossRef]

18. Taborga, L.; Vergara, A.; Osorio, M.; Carvajal, M.; Madrid, A.; Marilaf, F.; Carrasco, H.; Espinoza, L. Synthesis and NMR structure determination of new linear geranylphenols by direct geranylation of activated phenols. J.Chil. Chem. Soc. 2013, 58, 1790-1796. [CrossRef]

19. Chukicheva, I.Y.; Fedorova, I.V.; Koroleva, A.A.; Kuchin, A.V. Synthesis of natural geranyhidroquinone analogs. Chem. Nat. Compd. 2015, 51, 1056-1058. [CrossRef]

20. Manners, G.; Jurd, L.; Stevens, K. Biogenetic-type syntheses of isoprenoid and diisoprenoid derivatives of orcinol. Tetrahedron 1972, 28, 2949-2959. [CrossRef]

21. Kregiel, D. Succinate Dehydrogenase of Saccharomyces cerevisiae-The Unique Enzyme of TCA Cycle-Current Knowledge and New Perspectives. In Dehydrogenases; Canuto, R., Ed.; IntechOpen: London, UK, 2012; Chapter 9; pp. $211-234$.

22. Rutter, J.; Winge, D.R.; Schiffman, J.D. Succinate dehydrogenase-Assembly, regulation and role in human disease. Mitochondrion 2010, 10, 393-401. [CrossRef] [PubMed]

23. Hajjawi, O. Succinate dehydrogenase: Assembly, regulation and role in human disease. EJSR 2011, 51, $133-142$.

24. Avenot, H.F.; Michailides, T.J. Progress in understanding molecular mechanisms and evolution of resistance to succinate dehydrogenase inhibiting (SDHI) fungicides in phytopathogenic fungi. Crop Prot. 2010, 29, 643-651. [CrossRef]

25. Qiao, L.; Zhai, Z.-W.; Cai, P.-P.; Tan, C.-X.; Weng, J.-Q.; Han, L.; Liu, X.-H.; Zhang, Y.-G. Synthesis, Crystal Structure, Antifungal Activity, and Docking Study of Difluoromethyl Pyrazole Derivatives. J. Heterocycl. Chem. 2019, 56, 2536-2541. [CrossRef]

26. Wang, H.; Zhai, Z.-W.; Shi, Y.-X.; Tan, C.-X.; Weng, J.-Q.; Han, L.; Li, B.-J. Novel trifluoromethylpyrazole acyl urea derivatives: Synthesis, crystal structure, fungicidal activity and docking study. J. Mol. Struct. 2018, 1171, 631-678. [CrossRef]

27. Wang, G.; Cui, P.; Bai, H.; Wei, S.; Li, S. Late-Stage C-H Functionalization of Nicotinamides for the Expedient Discovery of Novel Antifungal Leads. J. Agric. Food Chem. 2019, 67, 11901-11910. [CrossRef] [PubMed]

28. Qiao, L.; Cai, P.-P.; Shen, Z.-H.; Wu, H.-K.; Tan, C.-X.; Weng, J.-Q.; Liu, X.-H. Crystal structure and molecular docking studies of new pyrazole-4-carboxamides. Heterocycl. Commun. 2019, 25, 66-72. [CrossRef]

29. Barghash, R.F.; Fawzy, I.M.; Chandrasekar, V.; Singh, A.V.; Katha, U.; Mandour, A.A. In Silico Modeling as a Perspective in Developing Potential Vaccine Candidates and Therapeutics for COVID-19. Coatings 2021, 11, 1273. [CrossRef]

30. Mansilla, D.S.; Torviso, M.R.; Alesso, E.N.; Vázquez, P.G.; Cáceres, C.V. Synthesis and characterization of copper and aluminum salts of H3PMo12O40 for their use as catalysts in the eco-friendly synthesis of chromanes. Appl. Catal. A Gen. 2010, 375, 196-204. [CrossRef]

31. Aknin, M.; Dayan, T.L.A.; Rudi, A.; Kashman, Y.; Gaydou, E.M. Hydroquinone antioxidants from the Indian Ocean tunicate Aplidium savignyi. J. Agric. Food Chem. 1999, 47, 4175-4177. [CrossRef]

32. Sato, A.; Shindo, T.; Kasanuki, N.; Hasegawa, K. Antioxidant Metabolites from the Tunicate Amaroucium-Multiplicatum. J. Nat. Prod. 1989, 52, 975-981. [CrossRef] [PubMed]

33. Oramas-Royo, S.; Haidar, S.; Amesty, Á.; Martín-Acosta, P.; Feresin, G.; Tapia, A.; Aichele, D.; Jose, J.; Estévez-Braun, A. Design, synthesis and biological evaluation of new embelin derivatives as CK2 inhibitors. Bioorganic Chem. 2020, 95, 103520. [CrossRef] [PubMed]

34. Singh, A.V.; Maharjan, R.-S.; Kanase, A.; Siewert, K.; Rosenkranz, D.; Singh, R.; Laux, P.; Luch, A. Machine-Learning-Based Approach to Decode the Influence of Nanomaterial Properties on Their Interaction with Cells. ACS Appl. Mater. Interfaces 2021, 13, 1943-1955. [CrossRef] [PubMed] 